\title{
Antiangiogenic Tyrosine Kinase Inhibitors in Metastatic Colorectal Cancer: Focusing on Regorafenib
}

\author{
MARIOS PAPADIMITRIOU and CHRISTOS A. PAPADIMITRIOU \\ Oncology Unit, Second Department of Surgery, “Aretaieion” University Hospital, \\ National and Kapodistrian University of Athens, Medical School, Athens, Greece
}

\begin{abstract}
The progress of metastatic colorectal cancer ( $m C R C$ ) depends essentially on two signaling pathways: the first mediated by vascular endothelial growth factor (VEGF) and the second by epidermal growth factor receptor (EGFR). In colorectal cancer (CRC), the balance between pro-angiogenic and anti-angiogenic factors is disturbed in favor of a proangiogenic outcome (angiogenic switch) early in the neoplastic progression of adenomas, thus, resulting in neovascularization and eventually in malignant tumor progression. Furthermore, angiogenesis plays an important role in tumor growth and the formation of metastases. Several angiogenic growth factors have been identified to be highly expressed during the progression and metastatic spread of CRC, but VEGFA is the predominant angiogenic cytokine and the most consistently expressed factor during the metastatic process. Agents targeting VEGF/VEGFR signaling have shown efficacy in the treatment of $m C R C$ and are currently approved in this setting. In this review, we summarize the role of antiangiogenic tyrosine kinase inhibitors (TKIs) in the treatment of $m C R C$, focusing on regorafenib.
\end{abstract}

CRC is the fourth most common tumor type in both sexes and the third most common cause of cancer death. More than 1.8 million new CRC cases and approximately 800,000 deaths occurred globally in $2018(1,2)$. Almost half of patients with resectable tumor at the time of initial diagnosis will eventually

This article is freely accessible online.

orrespondence to: Professor Christos A. Papadimitriou, MD, Ph.D., Chief, Oncology Unit, "Aretaieion” University Hospital, National and Kapodistrian University of Athens, V. Sophias 76, 11528 Athens, Greece. Tel: +30 2107286305, e-mail: chr_papadim@yahoo.gr

Key Words: Metastatic colorectal cancer, angiogenesis, VEGF, VEGFR, anti-angiogenic tyrosine kinase inhibitors (TKIs), regorafenib, review. develop metastases, while one in four patients will be diagnosed with primary metastatic disease. For stage IV patients, survival rates at five years range from $5 \%$ to $15 \%(3,4)$.

Initiation, progression and metastatic spread of CRC depend on various signaling pathways, the most prominent of these are the VEGF and the EGFR pathways (5-7). VEGF family proteins and their receptors (VEGFRs) play a central role in tumor angiogenesis, activating multiple signaling networks that result in endothelial cell growth, vessel formation, increased vascular permeability, tumor survival, proliferation and metastatic spread. Therefore, up-regulation of angiogenesis is a critical process for sustained tumor growth and is also of particular importance in the development of metastases (8-11). The angiogenic effects of the VEGF ligands are mediated by binding to cognate tyrosine kinase receptors (TKRs) on the cell surface (7-9), thus, causing their homo- and heterodimerization and activation through transphosphorylation. Phosphorylation is followed by the activation of a series of signaling pathways, such as RAS-RAF-MAPK, FAK-SRC, or AKT-mTOR (12).

In mCRC therapeutics, various agents have been used to inhibit angiogenesis, such as (a) monoclonal anti-VEGF antibodies that bind and neutralize VEGF; (b) a fusion soluble protein consisting of the ligand-binding domains of VEGFR1 and VEGFR-2 that are fused to the Fc portion of human IgG1 and acting, therefore, as soluble "decoy" receptor; (c) monoclonal antibodies that target VEGFR; (d) cytotoxic agents that inhibit angiogenic chemokines; (f) peptibodies; and (g) orally available inhibitors that target several TKRs involved in both tumor growth and angiogenesis.

In this review article, we will focus on the role of TKIs and especially regorafenib in $\mathrm{mCRC}$.

\section{Regorafenib: Structure and Mechanism of Action}

Regorafenib is a potent multi-kinase inhibitor that belongs to the group of biaryl urea chemicals and has activity against several protein kinases related to the angiogenic pathway 
(VEGFR-1/2/3, TIE2, PDGFR- $\alpha / \beta$, and FGFR-1/2), the oncogenic pathway (KIT, RAF1, BRAF, and RET), the metastatic process, and the immunosuppressive activity of the tumor microenviroment (13-17). Regorafenib was discovered in a program aimed at optimizing the potency and other pharmacological properties of known urea class compounds, such as sorafenib, which is a successful prototype of diphenylurea derivatives. The only structural difference between regorafenib and sorafenib is that the former has a fluorine atom in the central phenyl ring. This modification of regorafenib results in a similar but distinct biochemical profile when compared with sorafenib $(13,17)$. In vitro, regorafenib inhibits various TKRs with $50 \%$ inhibitory concentration $\left(\mathrm{IC}_{50}\right)$ values ranging from 4.2 to $311 \mathrm{nM} / 1$ for angiogenic TKRs, from 1.5 to $7 \mathrm{nM} / 1$ for oncogenic TKRs, from 22 to $202 \mathrm{nM} / 1$ for stromal kinases and from 2.5 to $28 \mathrm{nM} / 1$ for intracellular signaling kinases $(13,17)$. Regorafenib is exclusively metabolized in the liver via cytochrome P3A4 and uridine diphosphate-glucuronosyltransferase 1A9, which increases the risk of drug-induced liver injury $(17,18)$.

\section{Phase II and III Clinical Trials With Regorafenib Monotherapy}

In the phase III CORRECT trial (19), patients with mCRC who had progressed after all approved standard therapies were randomized to receive best supportive care (BSC) plus $160 \mathrm{mg}$ oral regorafenib or placebo, once every day for three weeks, followed by one week off treatment. All patients had received previous anti-VEGF treatment and $48 \%$ of them $>3$ prior lines of treatment in the metastatic setting. Median overall survival (OS) was 6.4 months in the regorafenib group versus 5.0 months in the placebo group [hazard ratio $(\mathrm{HR})=0.77 ; p=0.0052]$. Median progression-free survival (PFS) was 1.9 months in the regorafenib group versus 1.7 months in the placebo group ( $\mathrm{HR}=0.49 ; p<0.0001)$. Clinical adverse events (AEs) of Grade $\geq 3$ included hand-foot skin reaction (HFSR), i.e., rash and numbness affecting the palms and soles $(17 \%)$, fatigue $(10 \%)$, hypertension $(7 \%)$, diarrhea $(7 \%)$, rash or desquamation $(6 \%)$, oral mucositis $(3 \%)$, and anorexia (3\%). Laboratory abnormalities of Grade $\geq 3$ included hypophosphatemia (4\%), thrombocytopenia (4\%), anemia (2\%), hyperbilirubinemia (2\%), and proteinuria (1\%). A post hoc analysis that assessed the efficacy and safety profile of regorafenib in Japanese and non-Japanese subpopulations participating in the CORRECT trial did not show significant differences between the two groups (20). Based on the results of the CORRECT trial, regorafenib was approved in 2012 by the FDA as monotherapy for patients with $\mathrm{mCRC}$ who have been previously treated with, or who cannot be given, other available treatments, including fluoropyrimidine-based chemotherapy, an anti-VEGF therapy and an anti-EGFR therapy (21).
The double-blind, placebo-controlled, phase III CONCUR trial (22) was designed to evaluate the efficacy and safety of regorefenib in Asian patients from China, Hong Kong, South Korea, Taiwan, and Vietnam who had refractory $\mathrm{mCRC}$. They were randomized in a $2: 1$ ratio to receive $\mathrm{BSC}$ plus regorafenib or placebo, exactly as in the CORRECT trial (19). Median OS (primary endpoint) was 8.8 months in the regorafenib group versus 6.3 months in the placebo group ( $\mathrm{HR}=0.55$; one-sided $p=0.00016)$ and median PFS 3.2 months versus 1.7 months, respectively ( $\mathrm{HR}=0.31$; one-sided $p<0.0001)$. The type and rate of clinical AEs of Grade $\geq 3$ did not differ significantly from those described in the CORRECT trial (19) with HFSR being again the most frequent adverse event (16\%). The post hoc subgroup analysis of Chinese patients (from mainland China, Taiwan, and Hong Kong), who were included in the CONCUR trial representing $84 \%$ of the overall population, showed that the TKI provided an OS and PFS benefit, compared to placebo, similar to that reported in CONCUR with no differences in toxicity and its management (23).

A Brazilian single-center, single-arm, phase IIb study enrolled patients who were antiangiogenic therapy-naïve (24). Almost half of them had received $\geq 4$ prior lines of therapy on or after diagnosis of mCRC. Median PFS was 3.5 months, and median OS 7.4 months. Disease control rate (DCR) by RECIST criteria was $51 \%$ and metabolic response rate by EORTC criteria $41 \%$. With the exception of a higher incidence of hypophosphatemia and hypertension, the safety profile of regorafenib was generally consistent with that previously reported in the randomized trials CORRECT (19, 20) and CONCUR $(22,23)$.

Finally, two phase II studies enrolled patients based on $K R A S$ and/or BRAF status. In particular, the prematurely stopped for failing to accrue PREVIUM trial (25) did not demonstrate, in the population analyzed, clinical activity of regorafenib in $K R A S$ - or $B R A F$-mutated $\mathrm{mCRC}$ with disease progression after first-line treatment with FOLFOXIRI plus bevacizumab. In the second study, the Japanese REVERCE trial (26), patients with KRAS exon 2 wild-type $\mathrm{mCRC}$ were randomized after failure of fluoropyrimidine, oxaliplatin, and irinotecan to receive sequential treatment with regorafenib followed by cetuximab with or without irinotecan (R-C arm), or the reverse sequence (C-R arm). Median OS was 17.4 months in the R-C arm and 11.6 months in the $\mathrm{C}-\mathrm{R}$ arm ( $\mathrm{HR}=0.61$; $p=0.0293$ ), while the quality of life (QoL) scores throughout the treatment were not significantly different between the two arms. Mutations in KRAS, NRAS, BRAF, and $E G F R$ and gene amplification of $H E R 2$, and MET were analyzed in circulating tumor DNA (ctDNA) extracted from patients' plasma. Oncogenic alterations were more common after $\mathrm{R}-\mathrm{C}$ than after $\mathrm{C}-\mathrm{R}$ sequence. 


\section{Observational Studies With Regorafenib Monotherapy in the Real-World Setting}

Regorafenib has also been evaluated in four single-arm, open-label studies that were performed in real-world setting. The REBECCA cohort study was designed as part of a French compassionate use program (Autorisation Temporaire d'Utilisation, ATU) to assess survival, safety, and potential prognostic factors for regorafenib treatment in patients with mCRC refractory to standard treatments (27). Of 1178 patients included in the ATU program, 654 were fully analyzed. Median OS was 5.6 months and the 12-month survival rate was $22 \%$. Independent prognostic factors with an unfavorable effect on survival were: poor performance status, time from initial diagnosis of mCRC to the start of regorafenib treatment $<18$ months, low initial regorafenib dose, $>3$ metastatic sites, presence of liver metastases, and KRAS mutations. Based on these variables, the authors constructed a prognostic model which categorized patients into three risk groups. Patients with low-, intermediate-, and high-risk score had a median OS of 9.2, 5.2, and 2.5 months, respectively. Eighty percent of patients experienced at least one regorafenib-related AE. In general, the activity and toxicity of regorafenib reported in REBECCA were similar to those observed in randomized trials.

The single-arm, phase IIIb CONSIGN trial (28) analyzed, across 25 countries, 2,864 patients with mCRC refractory to standard therapy who received regorafenib in an expanded access program prior to market authorization. The primary endpoint of the study was safety. Clinical drug-related AEs of Grade $\geq 3$ were observed in $57 \%$ of patients, and included hypertension (15\%), HFSR (14\%), fatigue (13\%), diarrhea $(5 \%)$, maculopapular rash $(3 \%)$, oral mucositis $(2 \%)$, and anorexia (2\%). Laboratory drug-related toxicities of Grade $\geq 3$ included hypophosphatemia $(5 \%)$, hyperbilirubinemia $(5 \%)$, and elevated aspartate aminotransferase and alanine aminotransferase serum (3\%) levels. Treatment-emergent AEs resulted in treatment discontinuation in $25 \%$ of patients, dose reduction in $46 \%$, and treatment interruption or delay in $68 \%$. Again, the frequency and rates of AEs were consistent with those reported in in the CORRECT $(19,20)$ and CONCUR $(22,23)$ trials. Median PFS of the entire cohort was 2.7 months. The subgroup with longer PFS tended to consist of a slightly higher proportion of patients with better performance status, absence of liver metastases and a longer interval from the time of diagnosis of metastatic disease as compared to the subgroup with shorter PFS. These findings are similar to those of the REBECCA study (27) described earlier.

The population of the international, prospective, observational CORRELATE study (29) consisted of approximately 1,000 patients with $\mathrm{mCRC}$ who had previously been treated with, or were not considered candidates for, other approved therapies and for whom the treating physician decided to treat them with regorafenib according to the local health authority approved label. Safety was the primary objective. The most common AEs of Grade $\geq 3$ included fatigue $(9 \%)$, HFSR $(7 \%)$ and hypertension (6\%). Dose reductions for AEs occurred in $24 \%$ of patients. Median OS and PFS were 7.7 months and 2.9 months, respectively. Finally, the recently published phase IIIb, REGARD study (30) that evaluated the safety and efficacy of TKI among Turkish patients with treatment-refractory disease showed similar toxicity profile and PFS (primary endpoints) to those reported in previous trials.

\section{Retrospective Analyses Comparing Regorafenib With TAS-102}

Sueda et al. (31), retrospectively analyzed a small number of mCRC patients whose disease had progressed after standard therapies and who were treated with either regorafenib or TAS-102, an oral formulation that combines trifluorothymidine (TFT) and the potent thymidine phosphorylase inhibitor tipiracil hydrochloride (TPI), in a molar ratio of 1:0.5 $(32,33)$. TAS-102 has successfully completed two randomized phase II/III studies $(34,35)$. In 2017, FDA approved TAS-102 as a third- or fourth-line treatment of mCRC, after chemotherapy and targeted therapeutics have failed (36).

The results of the Japanese study showed that both agents had comparable efficacy but different toxicity profile. In the regorafenib group, median PFS and OS were 3.0 and 5.8 months, respectively, and in the TAS-102 group, 2.1 and 6.3 months, respectively. It is worth noting, that the median OS was 11.5 months in patients initially receiving regorafenib and at disease progression TAS-102, but only 7.6 months in those receiving the reverse sequence. Another Japanese study that retrospectively analyzed a larger number of patients came to the same conclusions (37).

A third Japanese study (REGOTAS) (38) retrospectively analyzed a much larger number of patients than the other two Japanese studies reported earlier. Median OS was 7.9 months in the regorafenib group and 7.4 months in the TAS-102 group. The propensity score adjusted analysis showed that OS was similar between the two treatment groups (adjusted $\mathrm{HR}=0.96 ; 95 \% \mathrm{CI}=0.78-1.18$ ). Interestingly, in the subgroup analysis, regorafenib showed better survival outcomes in patients aged $<65$ years $(\mathrm{HR}=1.29 ; 95 \% \mathrm{CI}=0.98-1.69)$, whereas TAS-102 in patients aged $\geq 65$ years $(\mathrm{HR}=0.78$; $95 \% \mathrm{CI}=0.59-1.03$ ).

Finally, a fourth retrospective Japanese study showed that patients that had previously received more systemic treatment lines, treated with regorafenib and were more likely to receive additional chemotherapy lines after disease progression on regorafenib compared to those treated with 
TAS-102 (39). In this comparative study, median OS was 9.9 and 11.4 months in the regorafenib and TAS-102 group, respectively, while median PFS was 2.0 and 3.3 months, respectively ( $\mathrm{HR}=0.52 ; p=0.00047)$. On the other hand, ORR and DCR did not differ. Median OS of patients receiving additional systemic therapies after disease progression was longer than that of patients without further treatment.

\section{Dose-escalation Trials of Regorafenib}

Despite the obvious survival benefits from the use of regorafenib in refractory $\mathrm{mCRC}$, the toxicity of the drug and especially HFSR and fatigue create problems in its therapeutic application. In the $\operatorname{CORRECT}(19,20)$ and CONCUR $(22,23)$ trials the standard dose of regorafenib was $160 \mathrm{mg}$, orally, once every day for three weeks, followed by one week off treatment. Data from clinical trials have shown that regorafenib-related AEs appear early after starting treatment, usually within the first cycle, and improve rather than worsen over time $(19,40)$. In clinical practice, physicians have usually adopted different dosing regimens or interval schedules to reduce toxicity. In this context, and in order to optimize the dosing strategy of regorafenib in patients with refractory mCRC, two phase II studies evaluated a dose-escalation strategy.

The randomized, multicenter, open-label, phase II study ReDOS, assessed the safety and activity of two regorafenib dosing schedules (41). Patients were randomly assigned into four groups with two different regorafenib dosing strategies and two clobetasol propionate cream usage plans. The steroid cream may help prevent HFSRs in patients receiving regorafenib. Dosing strategies included a dose-escalation strategy (initial dose of regorafenib $80 \mathrm{mg}$, once every day, with a weekly dose increase of $40 \mathrm{mg}$ to the final dose of 160 $\mathrm{mg}$, once every day, if no significant drug-related AEs occurred) and a standard-dose strategy (160 mg of regorafenib, once every day for three weeks, followed by one week off treatment). The primary endpoint, which was the proportion of patients in each group who completed two cycles of treatment and initiated the third cycle, was met, i.e., significantly more patients in the dose-escalation group started cycle 3 than in the standard-dose group (one-sided $p=0.043$ ). The most common AEs of Grade $\geq 3$ were fatigue (13\% of patients in the dose-escalation group versus $18 \%$ in the standard-dose group), HFSR (15\% versus $16 \%$ ), abdominal pain $(17 \%$ versus $6 \%)$, and hypertension ( $7 \%$ versus $15 \%)$.

In the single-arm, phase II RESET trial (42), 70 Japanese patients were treated with a lower starting dose of regorafenib (120 mg, once every day) and then the dosage was increased to $160 \mathrm{mg}$, once every day, on day 15 of the first cycle in patients who met dose escalation criteria, i.e., they did not experience HFSR of any Grade and treatmentrelated AEs of Grade $\geq 2$. Pharmacokinetics of total and unbound drug and its active metabolites were assessed. Only 6 patients $(8.6 \%)$ achieved dose escalation to $160 \mathrm{mg}$, on day 15 , as planned. DCR (primary endpoint) was $32.4 \%$, which was below the threshold of the statistical hypothesis. Serum concentrations of total regorafenib in patients whose dose was increased to $160 \mathrm{mg}$ were significantly lower than the relative serum concentrations in patients whose dose was not increased. Furthermore, non-bound serum concentrations of the sum of regorafenib and active metabolites were significantly correlated with the maximum Grade of regorafenib-related symptomatic AEs in the first cycle. In addition to the aforementioned dose escalation trials, another retrospective Japanese study examined the effectiveness of a reduced initial dose of regorafenib compared to the standard starting dose using a national database (43). Median OS was 12.6 months in the reduced dose group and 12.3 months in the standard dose group $(p=0.41)$. As expected, most AEs occurred less frequently in the reduced dose group.

\section{Regorafenib in Elderly Patients}

Two phase II trials assessed the efficacy and safety of regorafenib in the elderly population. An Italian study evaluated an alternative schedule in patients $\geq 75$ years old (44). They received regorafenib $160 \mathrm{mg}$, once every day for two weeks, followed by one week off treatment (2/1 schedule). The initial dose was reduced to $120 \mathrm{mg}$ in patients considered vulnerable or with more than one comorbidities, and to $80 \mathrm{mg}$ in patients $\geq 80$ years old or with ECOG $\mathrm{PS}=2$. DCR two months after treatment initiation (primary endpoint) was $52.2 \%$. Median PFS was 4.8 months and median OS 8.9 months, respectively. Interestingly, AEs were uncommon, and the most frequent Grade 3 toxicities were HFSR (9\%) and fatigue (9\%). Another French, single-arm, phase II trial (FFCD 1404-REGOLD), evaluated regorafenib at the approved dose in patients $\geq 70$ years old (45). The two-month DCR after treatment initiation (primary endpoint) was $31.4 \%$. Median PFS and OS were 2.2 and 7.5 months, respectively. The median time to autonomy degradation and QoL degradation were 3.1 and 3.2 months, respectively. Treatment-related AEs of Grade $\geq 3$ were observed in $83 \%$ of patients, in particular fatigue $(45.2 \%)$, HFSR (19.0\%), hypertension $(21.4 \%)$, and diarrhea $(7.1 \%)$. Both studies indicate that regorafenib can be given to elderly patients with similar efficacy compared with younger patients in previous studies. Dose reductions may result in a favorable toxicity profile without compromising antitumor activity, in terms of PFS and OC.

\section{Regorafenib in Combination With Chemotherapy}

Regorafenib plus multi-agent chemotherapy. A multicenter, phase Ib study explored whether the addition of regorafenib to the regimens FOLFOX or FOLFIRI could be feasible as 
first- or second-line treatment of mCRC, in terms of safety and pharmacokinetic interactions of the various drug components of the combination. Among patients evaluated for response, the rates of partial response and disease stabilization were $18.4 \%$ and $68.4 \%$, respectively. Median PFS was 116 days in the FOLFOX group, and 186.5 days in the FOLFIRI group. It should be noted that $>50 \%$ of patients required a reduction in the dose of chemotherapy due to AEs and this could explain the relatively low clinical efficacy observed in this trial (46).

The international, multicenter, single-arm, open-label, phase II CORDIAL trial (47) investigated the addition of regorafenib to modified FOLFOX6 as first-line treatment of mCRC. The combination did not improve ORR over historical controls. Median OS was not reached, whereas median PFS was 8.5 months. Regorafenib plus modified FOLFOX6 did not appear to be associated with a significantly worse tolerability profile compared to modified FOLFOX6 alone.

The addition of regorafenib to FOLFIRI, as a second-line treatment, showed only a modest increase in PFS compared to FOLFIRI alone, in another phase II trial that randomized patients with disease progression after first-line chemotherapy with oxaliplatin and fluoropyrimidine in a 2:1 ratio to FOLFIRI plus regorafenib or FOLFIRI plus placebo (48). Median PFS was 6.1 months with FOLFIRI plus regorafenib versus 5.3 months with FOLFIRI plus placebo $(\mathrm{HR}=0.73$; 95\% CI $=0.53$ $1.01 ; p=0.056$ ), while no differences in OS were observed between the two arms $(\mathrm{HR}=1.01 ; 95 \% \mathrm{CI}=0.71-1.44)$. Treatment-emergent AEs of Grade $\geq 3$ with a $>5 \%$ absolute increase from regorafenib included diarrhea, neutropenia, febrile neutropenia, hypophosphatemia, and hypertension.

In contrast to the findings of the two aforementioned prospective studies which did not show any particular benefit from the addition of regorafenib to first- or second-line chemotherapy, a retrospective cohort study from Taiwan (49) showed that the combination of regorafenib with chemotherapy (either single regimen 5-FU, irinotecan, oxaliplatin, or combination regimen FOLFIRI/FOLFOX), in the various treatment lines of $\mathrm{mCRC}$, resulted in superior OS (20.9 months versus 10.3 months, $p=0.015$ ). In a more recent, prospective trial from the same country, patients with disease progression after all approved standard therapies were subjected to UGT1Al genotyping and received in the third- or fourth-line setting the combination of regorafenib and FOLFIRI with dose-escalated irinotecan (50). The overall DCR was 58.5\%, whereas the median PFS and OS were 6.0 months and 12.0 months, respectively. Patients with wild-type KRAS had a significantly longer OS compared to those with KRAS mutations (14.4 versus 6.0 months; $\mathrm{HR}=0.40 ; p=0.014)$ but no significant difference was observed in PFS (9.0 versus 3.5 months; $\mathrm{HR}=0.57 ; p=0.117$ ). Positive EGFR expression had an inverse correlation with PFS and OS. Moreover, left-sided tumors were associated with superior PFS and OS. The same research group is conducting a phase II study that randomizes patients in a 2:1 ratio to FOLFIRI (with irinotecan dose escalation according to UGT1Al genotyping) plus $120 \mathrm{mg}$ regorafenib or to regorafenib alone (51).

Regorafenib plus TAS-102. The combination of regorafenib with TAS-102 is also interesting. The phase I trial REMETY (52) performed with a conventional $3+3$ dose finding aimed to determine the recommended phase II dose of this combination and its efficacy in the third- or fourth-line of treatment. DCR after 8 weeks was $58.3 \%$, remarkably better compared to historical data with regorafenib or TAS-102 alone. Furthermore, toxicities were consistent with the safety profile of each of the two agents alone.

\section{Combination of Regorafenib With Immune Checkpoint Inhibitors}

The phase Ib REGONIVO, EPOC1603 trial (53) assessed the safety and efficacy of regorafenib plus nivolumab for patients with metastatic gastric cancer and mCRC. It has been shown in experimental murine models of CRC that regorafenib reduces the number of tumor-associated macrophages (TAMs) (54), which have a tumor-promoting phenotype, primarily through suppression of T-cell mediated anti-tumor immune response (55). It has also been found in patients with gastric cancer that targeting VEGFR-2 reduces immunosuppressive regulatory $\mathrm{T}$ cells (Tregs) within the tumor microenvironment (56). Therefore, regorafenib is expected to have a similar effect since it is a VEGFR TKI. REGONIVO, EPOC1603 trial enrolled 25 patients with gastric cancer and 25 patients with CRC who had received $\geq 2$ previous lines of chemotherapy, including antiangiogenetic inhibitors in $96 \%$ of them. ORR was $44 \%$ in patients with gastric cancer and $36 \%$ in patients with CRC, while median PFS was 5.6 and 7.9 months, respectively. The combination had a manageable toxicity profile.

Selected ongoing phase I and II clinical trials investigating regorafenib in combination with other agents in $\mathrm{mCRC}$ are presented in Table I. Ongoing randomized trials are presented in Table II.

\section{Systematic Reviews and Meta-analyses of Regorafenib Trials}

The randomized phase III trials CORRECT (19) and CONCUR (22) showed that regorafenib when compared to placebo significantly increased PFS and OS with survival benefits of 1.4 and 2.5 months, respectively. A meta-analysis of 14 abstracts and 10 articles, demonstrated an even greater treatment effect on PFS $(\mathrm{HR}=0.40)$ and OS $(\mathrm{HR}=0.67)$ compared to placebo. These results were mainly supported 
Table I. Selected ongoing phase I and II clinical trials investigating regorafenib in combination with other agents in metastatic colorectal cancer.

\begin{tabular}{|c|c|c|c|c|}
\hline Study identifier & Type of study & Study population & Regimen/Treatment arms & Status \\
\hline NCT03305913 & $\begin{array}{l}\text { Phase I } \\
\text { (REMETY) }\end{array}$ & $\begin{array}{l}\text { Third-line treatment for patients who had previously } \\
\text { received at least one fluoropyrimidine-based } \\
\text { chemotherapy, an anti-VEGF and, in case of } R A S \mathrm{wt}^{\mathrm{a}} \\
\text { tumors, an anti-EGFR treatment }\end{array}$ & $\begin{array}{l}\text { Regorafenib plus TAS-102 } \\
(3+3 \text { dose finding strategy })\end{array}$ & Recruiting \\
\hline NCT03712943 & Phase I & $\begin{array}{l}\text { Patients with } \mathrm{pMMR}^{\mathrm{b}} / \mathrm{MSS}^{\mathrm{c}} \text { disease that progressed } \\
\text { through or become intolerant to fluoropyrimidine, } \\
\text { irinotecan, oxaliplatin, and bevacizumab, and if } K R A S \\
\text { wt, cetuximab or panitumumab containing therapies }\end{array}$ & Regorafenib plus Nivolumab & $\begin{array}{l}\text { Active, } \\
\text { not } \\
\text { recruiting }\end{array}$ \\
\hline NCT04362839 & Phase I & $\begin{array}{l}\text { Patients with pMMR/MSS disease that progressed } \\
\text { within six months following the last administration } \\
\text { of approved standard therapies which must include } \\
\text { a fluoropyrimidine, oxaliplatin, irinotecan and } \\
\text { anti-EGFR agent }\end{array}$ & $\begin{array}{l}\text { Regorafenib orally, once } \\
\text { every day for three weeks, } \\
\text { followed by one week off } \\
\text { treatment plus Nivolumab IV, } \\
\text { every } 2 \text { weeks plus } \\
\text { Ipilimumab IV, every } 6 \text { weeks }\end{array}$ & Recruiting \\
\hline NCT03828799 & $\begin{array}{l}\text { Phase I/II } \\
\text { (FOLFIRINOX-R) }\end{array}$ & $\begin{array}{l}\text { First-line treatment in patients with } \\
R A S \text { mutated mCRC }\end{array}$ & $\begin{array}{l}\text { FOLFIRINOX plus } \\
\text { Regorafenib }\end{array}$ & Recruiting \\
\hline NCT03657641 & Phase I/II & $\begin{array}{l}\text { Patients who had failed or are intolerant of } \\
\text { oxaliplatin, irinotecan, and 5-FU }\end{array}$ & $\begin{array}{l}\text { Pembrolizumab IV over } 30 \\
\text { minutes on day } 1 \text { plus } \\
\text { Regorafenib orally, on } \\
\text { days } 1 \text { to } 14\end{array}$ & Recruiting \\
\hline
\end{tabular}

aWild-type; ${ }^{b}$ proficient mismatch-repair; ${ }^{c}$ microsatellite stable.

by the non-randomized studies. The most frequently reported AEs were HFSR (25\%-86\%), hypertension (11\%-47\%) and fatigue $(2 \%-73 \%)(57)$. Another meta-analysis published in 2018 came to the same conclusions (58).

The first meta-analysis that assessed the efficacy and safety of regorafenib versus TAS-102 in mCRC (59) included the randomized trials CORRECT (19) and CONCUR (22) of regorafenib and the RECOURSE trial (60) of TAS-102. When compared with placebo, regorafenib demonstrated benefit for OS $(\mathrm{HR}=0.67 ; 95 \% \mathrm{CI}=0.48-0.93)$ with TAS-102 showing a similar magnitude of benefit $(\mathrm{HR}=0.69 ; 95 \% \mathrm{CI}=0.57-0.83)$ in direct comparison. Also, no differences were observed in PFS, ORR, and DCR. However, regorafenib was associated with more significant toxicity of any Grade (Risk Difference $=0.31$; 95\%CI=0.25-0.38; $p=0.001$ ), especially HFSR and fatigue. On the other hand, regorafenib showed less hematologic toxicity. In the indirect comparison, no statistically significant differences were observed between regorafenib and TAS-102 in terms of OS $(\mathrm{HR}=0.96 ; 95 \% \mathrm{CI}=0.57-1.66 ; p=0.91)$ or $\mathrm{PFS}(\mathrm{HR}=0.85$; $95 \% \mathrm{CI}=0.40-1.81 ; p=0.67)$. Similar results were published by Sonbol et al. (61) in their meta-analysis of regorafenib and TAS-102, which included the following trials: CORRECT (19), CONCUR (22), ReDOS (41), RECOURSE (58), the double-blind, placebo-controlled, phase III trial TERRA of TAS-102 monotherapy in Asian patients (62), and a Japanese double-blind, randomized, placebo-controlled phase II trial of TAS-102 (63).
Finally, three meta-analyses compared regorafenib, TAS102 and fruquintinib in refractory mCRC. All concluded that the three agents had similar OS but fruquintinib was superior, in terms of PFS, when compared with TAS-102. Furthermore, fruquintinib was associated with significantly increased risk for severe AEs compared with regorafenib and TAS-102 (64-66).

\section{Other TKIs in mCRC}

Sorafenib. Sorafenib is a multikinase inhibitor with activity against intracellular (CRAF, BRAF and mutant V600E BRAF) and cell surface kinases (KIT, FLT-3, VEGFR-1/2/3, RET, and PDGFR- $\beta$ ) (67-69). Sorafenib has been approved for the treatment of hepatocellular carcinoma, advanced renal cell carcinoma, refractory to radioactive iodine differentiated thyroid carcinoma, and FLT3-Internal Tandem Duplication (ITD) positive acute myeloid leukemia. In the RESPECT trial (70), patients with mCRC were randomized to receive as first-line treatment sorafenib or placebo, combined with mFOLFOX6. Median PFS and OS in the experimental and control arm, respectively, were 9.1 versus 8.7 months $(\mathrm{HR}=0.88 ; p=0.46)$, and 17.6 versus 18.1 months $(\mathrm{HR}=1.13$; $p=0.51$ ), respectively. In addition, there were no differences in survival outcomes between the two treatment arms by $K R A S, B R A F$ or PIK3CA status. The most common AEs of Grade $\geq 3$ in the sorafenib and placebo arms were neutropenia ( $48 \%$ versus $22 \%$ ), peripheral neuropathy (16\% 
versus $21 \%$ ), and HFSR (20\% versus $0 \%$ ). The authors concluded that these results do not support the further development of sorafenib in combination with mFOLFOX6 in molecularly non selected patients with mCRC.

In another randomized phase II trial (NEXIRI 2-PRODIGE 27) (71), patients with $R A S$ mutated mCRC, who had progressed after all approved standard therapies were randomized in 3 arms: NEXIRI (400 mg of oral sorafenib, twice daily, combined with irinotecan $120 \mathrm{mg} / \mathrm{m}^{2}$ in cycle 1 ; doses were increased to $150 \mathrm{mg} / \mathrm{m}^{2}$ in cycle 2 and $180 \mathrm{mg} / \mathrm{m}^{2}$ in cycle 3 if patients had no diarrhea of Grade $>1$ and no other toxicity of Grade >2) versus irinotecan alone $\left(180 \mathrm{mg} / \mathrm{m}^{2}\right)$ versus sorafenib alone, until disease progression or unacceptable toxicity, with cross-over to NEXIRI in the two monotherapy arms at disease progression. Median PFS was 3.7, 1.9, and 2.1 months in the NEXIRI, irinotecan, and sorafenib arm, respectively. It is worth noting, that patients with the CCND1rs9344 A/A genotype were more likely to benefit.

Sunitinib. Sunitinib is another oral TKI with activity against VEGFR, PDGFR, KIT, RET, and FLT-3 (72, 73). Sunitinib has been approved for the treatment of unresectable or metastatic gastrointestinal stromal tumors (GISTs) after failure of imatinib treatment, advanced renal cell carcinoma, and pancreatic neuroendocrine tumors. In a phase II trial, Saltz et al. (74), treated patients with mCRC, after failure of standard therapy, with oral sunitinib $50 \mathrm{mg}$, once every day for four weeks, followed by two weeks off treatment (schedule 4/2). Sunitinib did not demonstrate a meaningful single-agent ORR in chemorefractory mCRC. However, the authors concluded that the mechanisms of action and the acceptable safety profile of this agent warrant further study in conjunction with standardized regimens for mCRC. In this context, an open-label phase I trial was conducted to evaluate the safety and pharmacokinetics of sunitinib in combination with FOLFIRI (75). Based on the promising results of this study, a double-blind, phase III study was conducted that randomized 768 patients with previously untreated mCRC to receive FOLFIRI and either sunitinib or placebo until disease progression. Median PFS for the sunitinib arm was 7.8 months versus 8.4 months for the placebo arm. In addition, treatment with sunitinib was associated with a higher rate of AEs of Grade $\geq 3$ than FOLFIRI plus placebo. Therefore, the authors concluded that the combination of FOLFIRI with sutinib is not recommended for previously untreated mCRC (76). Relevant are the results of a phase II study that investigated the same combination as first-line treatment in patients with liver metastases (77).

Vatalanib. Vatalanib is an orally available TKI with activity against VEGFR-1/2/3, KIT, PDGFR and FMS (78). In a phase IB trial, FOLFOX4 was combined with vatalanib at escalating doses. Median PFS was 11.4 months (79). In another phase I/II study, vatalanib was combined with FOLFIRI as first-line treatment in patients with mCRC. Preliminary results suggested that the combination was safe, well tolerated, and had activity (80). Therefore, vatalanib was subsequently evaluated in two randomized phase III trials. In the first-line setting, 1,168 patients were randomly assigned to receive FOLFOX4 plus valatanib or placebo (81). Median PFS was 7.7 months with vatalanib versus 7.6 months with placebo $(\mathrm{HR}=0.88 ; p=0.118)$, while median OS was 21.4 versus 20.5 months $(\mathrm{HR}=1.08$; $p=0.260$ ), respectively. In a post hoc subgroup analysis of patients with high serum LDH, a potential marker of hypoxia, PFS was 7.7 months with vatalanib versus 5.8 months with placebo $(\mathrm{HR}=0.67 ; p=0.009)$.

In the other phase III trial, patients with pretreated mCRC were randomly assigned to receive FOLFOX4 and either vatalanib or placebo (82). Median OS was 13.1 with vatalanib versus 11.9 months with placebo $(\mathrm{HR}=1.00$; $p=0.957$ ), respectively. On the other hand, median PFS was longer with vatalanib than with placebo (5.6 versus 4.2 months, respectively; HR=0.83; $p=0.013$ ). Again, a post hoc analysis demonstrated improved PFS in patients with high $\mathrm{LDH}$, regardless of performance status $(\mathrm{HR}=0.63 ; p<0.001)$. However, both phase III trials are considered negative studies, as their primary endpoints (PFS in the first and OS in the second) were not met.

Tivozanib. Tivozanib is a selective oral TKI with a long halflife and activity against VEGFR-1/2/3 (83). Tivozanib has been approved by EMA for the treatment of metastatic renal cell carcinoma. In a phase Ib study, patients with advanced gastrointestinal tumors were treated with tivozanib $(0.5 \mathrm{mg}$, $1.0 \mathrm{mg}$, or $1.5 \mathrm{mg}$ orally, once every day for three weeks, followed by one week off treatment) in combination with mFOLFOX6. Among 30 patients, 1 had an ongoing clinical complete response of more than 2.5 years, and 10 had a partial response, for an ORR of $37 \%$. Another 11 patients experienced disease stabilization, lasting from 1.8 to 24.6 months. Furthermore, treatment appeared to be safe (84).

Based on these very encouraging results, an open-label, randomized phase II trial (BATON-CRC) (85) of tivozanib plus mFOLFOX6 versus bevacizumab plus mFOLFOX6 in treatment-naïve patients with $\mathrm{mCRC}$ was initiated. The combination of tivozanib and mFOLFOX6 was tolerable. Median PFS was 9.4 months for tivozanib plus mFOLFOX6 versus 10.7 months for bevacizumab plus mFOLFOX6 $(\mathrm{HR}=1.091 ; p=0.706)$. Also, tivozanib plus mFOLFOX6 resulted in ORR comparable with that of bevacizumab plus mFOLFOX6 (45.2\% versus $43.2 \%$, respectively). Of note, PFS in patients with low neuropilin-1 (NRP-1) was 17.9 months in the tivozanib arm versus 11.2 months in the bevacizumab arm $(\mathrm{HR}=0.38$; unstratified $p=0.0075)$. For patients with high NRP-1, no differences in PFS were observed between the two arms. 
Table II. Selected ongoing randomized phase II and phase IIII clinical trials investigating regorafenib in combination with other agents in metastatic colorectal cancer.

\begin{tabular}{|c|c|c|c|c|}
\hline Study identifier & Type of study & Study population & Regimen/Treatment arms & Status \\
\hline NCT03880877 & $\begin{array}{l}\text { Randomized } \\
\text { Phase II }\end{array}$ & $\begin{array}{l}\text { Patients for whom the decision has been made } \\
\text { per investigator's routine treatment practice to } \\
\text { prescribe regorafenib as third-line (RAS mut) or } \\
\text { fourth-line }\left(R A S \mathrm{wt}^{\mathrm{a}}\right) \text { therapy }\end{array}$ & $\begin{array}{l}\text { Comparator arm: Regorafenib } \\
120 \mathrm{mg} \text { orally, once every } \\
\text { day for three weeks, followed } \\
\text { by one week off treatment } \\
\text { Experimental arm: Regorafenib } \\
\text { plus Irinotecan }\left(180 \mathrm{mg} / \mathrm{m}^{2}\right. \\
\text { as a } 120 \text {-min IV infusion for } \\
\text { TA6/6 wt and TA6/7 UGTIA1 } \\
\text { genotypes or } 120 \mathrm{mg} / \mathrm{m}^{2} \text { for } \\
\text { TA7/7 UGT1A1 genotype), } \\
\text { followed by Leucovorin } \\
\text { ( } 400 \mathrm{mg} / \mathrm{m}^{2} \text { as a } 120 \text {-min IV } \\
\text { infusion), and } 5 \text {-FU } \\
\left(2,800 \mathrm{mg} / \mathrm{m}^{2} \text { IV infusion over }\right. \\
\text { a } 46-\text { hour period), repeated } \\
\text { every } 2 \text { weeks (FOLFIRIc) }\end{array}$ & Recruiting \\
\hline NCT04008511 & $\begin{array}{l}\text { Phase Ib/ } \\
\text { Randomized } \\
\text { Phase II }\end{array}$ & $\begin{array}{l}\text { Second-line treatment in patients with disease } \\
\text { progression after first-line treatment } \\
\text { with 5-FU and irinotecan }\end{array}$ & $\begin{array}{l}\text { Comparator arm: Oxaliplatin } \\
130 \mathrm{mg} / \mathrm{m}^{2}, \text { IV on day } 1, \\
\text { and Capecitabine } 1,000 \mathrm{mg} / \mathrm{m}^{2}, \\
\text { bid orally for } 14 \text { days }(\mathrm{XELOX}) \\
\text { Experimental arm: Regorafenib } \\
\mathrm{MAD}^{\mathrm{d}} \text { orally, once every day } \\
\text { for two weeks, followed by one } \\
\text { week off treatment plus XELOX }\end{array}$ & $\begin{array}{l}\text { Not yet } \\
\text { recruiting }\end{array}$ \\
\hline NCT01298570 & $\begin{array}{l}\text { Randomized } \\
\text { Phase II }\end{array}$ & $\begin{array}{l}\text { Second-line treatment for patients with } \\
\text { disease progression during or within } 6 \text { months } \\
\text { after first-line treatment with oxaliplatin plus } \\
5 \text {-FU (with or without LV) or capecitabine } \\
\text { with or without bevacizumab }\end{array}$ & $\begin{array}{l}\text { Arm A: FOLFIRI plus Placebo } \\
\text { Arm B: FOLFIRI plus } \\
\text { Regorafenib } 160 \text { mg orally, } \\
\text { once every day, days } 4 \text { to } 10 \text { and } \\
\text { days } 18 \text { to } 24 \text {, every four weeks }\end{array}$ & $\begin{array}{l}\text { Active not } \\
\text { recruiting }\end{array}$ \\
\hline NCT04117945 & $\begin{array}{l}\text { Randomized } \\
\text { Phase II } \\
\text { (REVERCE II) }\end{array}$ & $\begin{array}{l}\text { Patients with } K R A S, N R A S \text { and } B R A F \mathrm{~V} 600 \mathrm{E} \\
\text { wt mCRC previously treated with } \\
\text { fluoropyrimidine, oxaliplatin and irinotecan }\end{array}$ & $\begin{array}{l}\text { Arm A: Regorafenib orally, once } \\
\text { every day for three weeks, } \\
\text { followed by one week off } \\
\text { treatment. Patients with disease } \\
\text { progression may switch over } \\
\text { to the other treatment regimen, } \\
\text { per treating physician discretion. } \\
\text { Arm } B \text { : Cetuximab or Panitumumab } \\
\text { IV on days } 1 \text { and } 15 \text { with or } \\
\text { without Irinotecan as determined } \\
\text { by the study doctor. Patients with } \\
\text { disease progression may switch } \\
\text { over to the other treatment regimen, } \\
\text { per treating physician discretion. }\end{array}$ & Recruiting \\
\hline NCT03844620 & $\begin{array}{l}\text { Randomized } \\
\text { Phase II }\end{array}$ & $\begin{array}{l}\text { Patients with disease progression after } \\
\geq 2 \text { prior lines of treatment including } \\
5 \text {-FU, oxaliplatin, irinotecan, bevacizumab, } \\
\text { and if } K R A S \text { wt cetuximab or panitumumab }\end{array}$ & $\begin{array}{l}\text { Comparator arm: Regorafenib } \\
\text { orally, once every day for } \\
\text { three weeks, followed by one } \\
\text { week off treatment or TAS-102 } \\
\text { orally, twice daily on days } 1 \text { to } \\
5 \text { and } 8 \text { to } 12 \text {, every four weeks, } \\
\text { as per SOCh, until disease } \\
\text { progression or unacceptable toxicity } \\
\text { Experimental Arm: Regorafenib } \\
\text { or TAS-102. Patients will get } \\
\text { ctDNAg testing and will continue } \\
\text { treatment beyond the first cycle } \\
\text { depending on ctDNA results } \\
\text { until disease progression or } \\
\text { unacceptable toxicity. }\end{array}$ & Recruiting \\
\hline
\end{tabular}


Papadimitriou and Papadimitriou: Regorafenib in Metastatic Colorectal Cancer (Review)

Table II. Continued

\begin{tabular}{|c|c|c|c|c|}
\hline Study identifier & Type of study & Study population & Regimen/Treatment arms & Status \\
\hline NCT03992456 & $\begin{array}{l}\text { Randomized } \\
\text { Phase II } \\
\text { (PULSE) }\end{array}$ & $\begin{array}{l}\text { Patients with KRAS wt disease that } \\
\text { progressed to a fluoropyrimidine, } \\
\text { oxaliplatin, irinotecan, and an anti-VEGF } \\
\text { monoclonal antibody or an anti-PD-1 } \\
\text { monoclonal antibody if tumor has } \\
\text { deficient } \mathrm{MMR}^{\mathrm{f}} \text { or is MSI- } \mathrm{H}^{\mathrm{h}}\end{array}$ & $\begin{array}{l}\text { Comparator arm: TAS- } 102 \\
\text { orally on days } 1 \text { to } 5 \text { and } 8 \text { to } \\
12 \text {, or Regorafenib orally, } \\
\text { once every day for three weeks, } \\
\text { followed by one week off } \\
\text { treatment (at the discretion } \\
\text { of the treating physician) } \\
\text { Experimental arm: Panitumumab } \\
\text { IV on days } 1 \text { and } 15 \text {, } \\
\text { every four weeks }\end{array}$ & Recruiting \\
\hline NCT03829462 & $\begin{array}{l}\text { Phase III } \\
\text { (NEXT-REGIRI) }\end{array}$ & $\begin{array}{l}\text { Patients with disease progression during } \\
\text { or within } 3 \text { months following the last } \\
\text { administration of all approved standard } \\
\text { therapies, which must include a fluoro- } \\
\text { pyrimidine, oxaliplatin, irinotecan, } \\
\text { anti-VEGF therapy and an anti-EGFR } \\
\text { therapy (for } R A S \text { wt tumors) }\end{array}$ & $\begin{array}{l}\text { Comparator arm: Regorafenib } \\
160 \mathrm{mg} \text { orally, once every } \\
\text { day for three weeks, followed } \\
\text { by one week off treatment } \\
\text { Experimental arm: Irinotecan } \\
180 \mathrm{mg} / \mathrm{m}^{2} \text { at day } 1 \text { of each } \\
\text { cycle plus Regorafenib } 160 \mathrm{mg} \\
\text { orally, once every day, days } 2 \text { to } 8\end{array}$ & Recruiting \\
\hline
\end{tabular}

aWild-type; b5-fluorouracil; cafter every 2 cycles of each different dose of irinotecan, if adverse events are Grade $<2$ dose will be escalated by $30 \mathrm{mg} / \mathrm{m}^{2}$ with an estimated maximal dose of $260 \mathrm{mg} / \mathrm{m}^{2}$ for TA6/6 UGT1A1 genotype TA6, $240 \mathrm{mg} / \mathrm{m}^{2}$ for TA6/7, and $180 \mathrm{mg} / \mathrm{m}^{2}$ for TA7/7; ${ }^{\mathrm{m} m a x i m u m}$ administered dose; ${ }^{\mathrm{s}}$ standard-of-care; $\mathrm{f}_{\text {circulating tumor; }} \mathrm{g}$ mismatch-repair; ${ }^{\mathrm{h}}$ microsatellite instability-high.

Vandetanib. Vandetanib is an oral TKI that targets VEGFR$1 / 2 / 3$, EGFR and RET (86). It has been approved for the treatment of advanced/metastatic medullary thyroid cancer. In a phase I study, vandetanib was tested in combination with cetuximab and irinotecan as second-line treatment in patients with mCRC (87). Seven percent of patients had a partial response, $59 \%$ stable disease and $34 \%$ progressed. Median PFS was 3.6 months and median OS 10.5 months. Toxicities were quite manageable with diarrhea of Grade $\geq 3$ being the common treatment-related AE (30\%). The observed effectiveness raised interest in further evaluating of this combination.

In another phase I study, vandetanib was combined with capecitabine and oxaliplatin, with and without bevacizumab, in the first-line setting (88). ORR was $46 \%$, while the time to disease progression ranged from 2 to 14 months. Oral vandetanib at doses of $100 \mathrm{mg}$ and $300 \mathrm{mg}$, daily, in combination with capecitabine and oxaliplatin was well tolerated. However, the addition of bevacizumab caused diarrhea of Grade 3 .

Nintedanib. Nintedanib is a small molecule with activity against receptor tyrosine and non-receptor tyrosine kinases, such as PDGFR- $\alpha / \beta$, FGFR-1/2/3, VEGFR-1/2/3, FLT-3, Lck, Lyn and Src (89). Nintedanib has been approved for the treatment of patients with interstitial lung disease associated with systemic sclerosis or scleroderma, and in combination with docetaxel for the treatment of patients with advanced/metastatic adenocarcinoma of the lung. The combination of nintedanib with chemotherapy was compared with the combination of bevacizumab with chemotherapy, in a randomized phase I/II study, as first-line treatment in patients with mCRC. In the phase II part, patients were randomized in a 2:1 ratio to receive nintedanib plus mFOLFOX6 or bevacizumab plus mFOLFOX6. PFS rate at 9 months was $62.1 \%$ in the nintedanib arm versus $70.2 \%$ in bevacizumab arm, while confirmed ORRs were $63.5 \%$ and $56.1 \%$, respectively. Furthermore, the safety profile of nintedanib in combination with mFOLFOX6 was manageable (90).

The LUME-Colon 1 trial (91) had the same design as the CORRECT $(19,20)$ and CONCUR $(22,23)$ trials. More specifically, this double-blind, placebo-controlled, phase III study assessed the efficacy and safety of oral nintedanib (200 $\mathrm{mg}$ twice daily) plus BSC versus placebo plus BSC in patients with mCRC who had progressed after all approved standard therapies. Median PFS was 1.5 months with nintedanib plus BSC versus 1.4 months with placebo plus $\mathrm{BSC}(\mathrm{HR}=0.58 ; p<0.0001)$, but this increase by $42 \%$ did not result in improved OS.

Fruquintinib. Fruquintinib (HMPL-013) is a highly selective TKI with activity against VEGFR-1/2/3 (92). A phase Ib openlabel study was followed by another phase II, randomized, placebo-controlled trial that evaluated the efficacy and safety of fruquintinib (5 mg orally, once every day for three weeks, followed by one week off treatment) plus BSC versus placebo 
plus BSC in patients with mCRC who had received at least two lines of prior therapies. In the randomized phase II trial, median PFS was 4.73 months with fruquintinib plus BSC versus only 0.99 months with placebo plus $\mathrm{BSC}(\mathrm{HR}=0.30$; $p<0.001)$. Patients who received fruquintinib had a longer median OS (7.72 versus 5.52 months), however, the difference was not statistically significant (93).

These encouraging results led to a phase III study (FRESCO-2) (94) with patients enrolled from 28 centers in China, who met similar inclusion criteria, and who were randomized in the same way and received exactly the same treatment as the patients of the aforementioned phase II study. Median PFS was significantly increased with fruquintinib (3.71 versus 1.84 months; $\mathrm{HR}=0.26 ; p<0.001$ ), but more importantly, OS (primary endpoint) was also significantly increased with the TKI ( 9.3 months in the fruquintinib arm versus 6.57 months in the placebo arm; $\mathrm{HR}=0.65 ; p<0.001)$. Statistically significant benefits were also seen with fruquintinib in the other secondary endpoints, such as ORR and DCR. The most frequent fruquintinib-related AEs of Grade $\geq 3$ included hypertension (21.2\%), HFSR (10.8\%), proteinuria $(3.2 \%)$, diarrhea $(2.9 \%)$, and thrombocytopenia $(2.5 \%)$. Based on the results of this trial, FDA granted fast track designation to fruquintinib for mCRC patients previously treated with fluoropyrimidine-, oxaliplatin- and irinotecan-based chemotherapy, an anti-VEGF biological therapy and -if RAS wild-type- an anti-EGFR therapy (95).

Famitinib. Famitinib (SHR1020) is a TKI that targets VEGFR-2/3, KIT and PDGFR- $\alpha / \beta$, RET, FLT-1 and FLT-3 (96). A multicenter, phase II clinical trial randomized in a 2:1 ratio patients with $\mathrm{mCRC}$ whose disease progressed after all available standard therapies to receive either famitinib or placebo. Median PFS was 2.8 in the famitinib arm versus 1.5 months in the placebo arm $(\mathrm{HR}=0.60 ; p=0.004)$. No significant differences in OS were observed between the two arms. The most frequent AEs of Grade $\geq 3$ included hypertension, HFSR, thrombocytopenia, and neutropenia (97).

Axitinib. Axitinib, an indazole derivative, is an oral, highly selective inhibitor of VEGFR-1/2/3 (98). In a multicenter, open-label, randomized phase 2 trial, patients with previously untreated $\mathrm{mCRC}$ were randomized in a 1:1:1 ratio to receive axitinib (5 mg, orally, twice a day), bevacizumab $(5 \mathrm{mg} / \mathrm{kg}$, intravenously, every 2 weeks), or axitinib ( $5 \mathrm{mg}$, orally, twice a day) plus bevacizumab $(2 \mathrm{mg} / \mathrm{kg}$, intravenously, every 2 weeks), each in combination with FOLFOX6. The addition of axitinib only or axitinib plus bevacizumab to chemotherapy did not improve ORR, PFS or OS compared to bevacizumab plus FOLFOX (99). Another phase II trial, randomized patients after failure of first-line therapy to chemotherapy (mFOLFOX-6 or FOLFIRI) plus either axitinib or bevacizumab. There were no significant differences in survival outcomes between the two treatment arms. AEs of Grade $\geq 3$ were more common with axitinib (100).

A recently published randomized phase II trial, evaluated the efficacy and safety of maintenance therapy with axitinib versus placebo following induction therapy. More specifically, patients with $\mathrm{mCRC}$ who had not progressed after 6 to 8 months of first-line chemotherapy were randomized to receive maintenance therapy with axitinib or placebo. Median PFS was 4.96 months in the axitinib arm versus 3.16 months in the placebo arm $(\mathrm{HR}=0.46 ; p=0.0116)$. Although median OS was also longer in the axitinib arm, this difference did not reach statistical significance (27.61 versus 19.99 months; HR=0.68; $p=0.3279$ ). Maintenance therapy had a good safety profile (101).

Apatinib. Apatinib (YN968D1) is a potent inhibitor of VEGFR-2, PDGFR- $\beta$, KIT and SRC (102). In a Chinese pilot study, apatinib was active as a third-line treatment of refractory mCRC with a manageable toxicity profile (103).

\section{Conclusion}

Numerous antiangiogenic TKIs have been tested in mCRC. Most of the clinical trials have evaluated regorafenib alone or in combination with other agents in the various treatment lines. Regorafenib is indicated for the treatment of patients with $\mathrm{mCRC}$ who have been previously treated with fluoropyrimidine-, oxaliplatin- and irinotecan-based chemotherapy, an anti-VEGF therapy, and, if KRAS wild-type, an antiEGFR therapy. In practice, the place of regorafenib is in the third- or fourth-line of treatment, where TAS-102 and more recently fruquintinib represent another option. Regorafenib and TAS-102 do not differ in terms of DCR, PFS and OS but have different toxicity profiles, which may guide the treatment choice. For better tolerance of regorafenib, the dose-escalation strategy has yielded acceptable results. The combination of regorafenib with other agents, especially immune checkpoint inhibitors, is also of interest. Among the other antiangiogenic TKIs, fruquintinib has given encouraging results.

\section{Conflicts of Interest}

MP has nothing to disclose. CAP has received speaker honoraria and honoraria for consultancy in advisory boards from Novartis, Pfizer, AstraZeneca, Genesis, MSD, Amgen, Merck and Roche and research grants from BMS and Roche.

\section{Authors' Contributions}

MP had the initial conception for the review, drafted the original manuscript, made substantial contributions to acquisition and interpretation of the literature, and has given final approval of the version to be published. 
CAP drafted the original manuscript, made substantial contributions to acquisition and interpretation of the literature, and has given final approval of the version to be published.

\section{References}

1 Ferlay J, Colombet M, Soerjomataram I, Mathers C, Parkin DM, Piñeros M, Znaor A and Bray F: Estimating the global cancer incidence and mortality in 2018: GLOBOCAN sources and methods. Int J Cancer 144(8): 1941-1953, 2019. PMID: 30350310. DOI: $10.1002 /$ ijc.31937

2 Aran V, Victorino AP, Thuler LC and Ferreira CG: Colorectal cancer: epidemiology, disease mechanisms and interventions to reduce onset and mortality. Clin Colorectal Cancer 15(3): 195203, 2016. PMID: 26964802. DOI: 10.1016/j.clcc.2016.02.008

3 Noone AM, Howlader N, Krapcho M, Miller D, Brest A, Yu M, Ruhl J, Tatalovich Z, Mariotto A, Lewis DR, Chen HS, Feuer EJ and Cronin KA (eds.): SEER Cancer Statistics Review, 19752015, National Cancer Institute. Bethesda, MD, U.S.A. Available at: https://seer.cancer.gov/csr/1975_2015/, based on November 2017 SEER data submission, posted to the SEER web site, April 2018.

4 De Greef K, Rolfo C, Russo A, Chapelle T, Bronte G, Passiglia F, Coelho A, Papadimitriou K and Peeters M: Multisciplinary management of patients with liver metastasis from colorectal cancer. World J Gastroenterol 22(32): 7215-7225, 2016. PMID: 27621569. DOI: 10.3748/wjg.v22.i32.7215

5 Tortora G, Ciardiello F and Gasparini G: Combined targeting of EGFR-dependent and VEGF-dependent pathways: rationale, preclinical studies and clinical applications. Nat Clin Pract Oncol 5(9): 521-530, 2008. PMID: 18594498. DOI: 10.1038/ncponc 1161

6 Winder T and Lenz HJ: Vascular endothelial growth factor and epidermal growth factor signaling pathways as therapeutic targets for colorectal cancer. Gastroenterology 138(6): 2163-2176, 2010. PMID: 20420953. DOI: 10.1053/j.gastro.2010.02

7 Mirone G, Shukla A and Marfe G: Signaling mechanisms of resistance to EGFR- and Anti-Angiogenic Inhibitors cancer. Crit Rev Oncol Hematol 97: 85-95, 2016. PMID: 26364891. DOI: 10.1016/j.critrevonc 2015.08 .012

8 Patan S: Vasculogenesis and angiogenesis. Cancer Treat Res 117: 3-32, 2004. PMID: 15015550. DOI: 10.1007/978-1-4419-88713_1

9 Carmeliet P and Jain RK: Principles and mechanisms of vessel normalization for cancer and other angiogenic diseases. Nat Rev Drug Discov 10(6): 417-427, 2011. PMID: 21629292. DOI: $10.1038 / \mathrm{nrd} 3455$

10 Carmeliet P and Jain RK: Molecular mechanisms and clinical applications of angiogenesis. Nature 473(7347): 298-307, 2011. PMID: 21593862. DOI: 10.1038/nature10144

11 Angelucci A, Delle Monache S, Cortellini A, Di Padova M and Ficorella C: "Vessels in the Storm": Searching for prognostic and predictive angiogenic factors in colorectal cancer. Int J Mol Sci 19(1): 299, 2018. PMID: 29351242. DOI: 10.3390/ijms19010299

12 Staton CA, Chetwood AS, Cameron IC, Cross SS, Brown NJ and Reed MW: The angiogenic switch occurs at the adenoma stage of the adenoma carcinoma sequence in colorectal cancer. Gut 56(10): 1426-1432, 2007. PMID: 17566019. DOI: 10.1136/ gut.2007.125286

13 Wilhelm SM, Dumas J, Adnane L, Lynch M, Carter CA, Schütz G, Thierauch KH and Zopf D: Regorafenib (BAY 73-4506): a new oral multikinase inhibitor of angiogenic, stromal and oncogenic receptor tyrosine kinases with potent preclinical antitumor activity. Int J Cancer 129(1): 245-255, 2011. PMID: 21170960. DOI: $10.1002 / \mathrm{ijc} .25864$

14 Zhao Y and Adjei AA: Targeting angiogenesis in cancer therapy: moving beyond vascular endothelial growth factor. Oncologist 20(6): 660-673, 205. PMID: 26001391. DOI: 10.1634/ theoncologist.2014-0465

15 Takigawa H, Kitadai Y, Shinagawa K, Yuge R, Higashi Y, Tanaka $\mathrm{S}$, Yasui $\mathrm{W}$ and Chayama K: Multikinase inhibitor regorafenib inhibits the growth and metastasis of colon cancer with abundant stroma. Cancer Sci 107(5): 601-608, 2016. PMID: 26865419. DOI: $10.1111 /$ cas.12907

16 Arai H, Battaglin F, Wang J, Lo JH, Soni S, Zhang W and Lenz HJ: Molecular insight of regorafenib treatment for colorectal cancer. Cancer Treat Rev 81: 101912, 2019. PMID: 31715423. DOI: $10.1016 /$ j.ctrv.2019.101912

17 Goel G: Evolution of regorafenib from bench to bedside in colorectal cancer: Is it an attractive option or merely a "me too" drug? Cancer Manag Res 10: 425-437, 2018. PMID: 29563833. DOI: $10.2147 / C M A R . S 88825$

18 Sacré A, Lanthier N, Dano H, Aydin S, Leggenhager D, Weber A, Dekairelle AF, De Cuyper A, Gala JL, Humblet Y, Sempoux $\mathrm{C}$ and Van den Eynde M: Regorafenib induced severe toxic hepatitis: characterization and discussion. Liver Int 36(11): 15901594, 2016. PMID: 27500989. DOI: 10.1111/liv.13217

19 Grothey A, Van Cutsem E, Sobrero A, Siena S, Falcone A, Ychou M, Humblet Y, Bouché O, Mineur L, Barone C, Adenis A, Tabernero J, Yoshino T, Lenz HJ, Goldberg RM, Sargent DJ, Cihon F, Cupit L, Wagner A and Laurent D; CORRECT Study Group: Regorafenib monotherapy for previously treated metastatic colorectal cancer (CORRECT): an international, multicentre, randomised, placebo-controlled, phase 3 trial. Lancet 381(9863): 303-312, 2013. PMID: 23177514. DOI: 10.1016/ S0140-6736(12)61900-X

20 Yoshino T, Komatsu Y, Yamada Y, Yamazaki K, Tsuji A, Ura T, Grothey A, Van Cutsem E, Wagner A, Cihon F, Hamada Y and Ohtsu A: Randomized phase III trial of regorafenib in metastatic colorectal cancer: analysis of the CORRECT Japanese and nonJapanese subpopulations. Invest New Drugs 33(3): 740-750, 2015. PMID: 25213161. DOI: 10.1007/s10637-014-0154-x

21 New Drug Application Approval. Available at: https:// www.accessdata.fda.gov/drugsatfda_docs/appletter/2012/203085 Orig1s0001tr.pdf [Last accessed on January 1, 2021]

22 Li J, Qin S, Xu R, Yau TC, Ma B, Pan H, Xu J, Bai Y, Chi Y, Wang L, Yeh KH, Bi F, Cheng Y, Le AT, Lin JK, Liu T, Ma D, Kappeler C, Kalmus J and Kim TW; CONCUR Investigators: Regorafenib plus best supportive care versus placebo plus best supportive care in Asian patients with previously treated metastatic colorectal cancer (CONCUR): a randomised, doubleblind, placebo-controlled, phase 3 trial. Lancet Oncol 16(6): 619629, 2015. PMID: 25981818. DOI: 10.1016/S1470-2045(15) 70156-7

23 Xu J, Xu RH, Qin S, Pan H, Bai Y, Chi Y, Wang L, Bi F, Cheng Y, Liu T, Ma D, Shen L, Ba Y, Liang J, Wang X, Yau TCC, Ma BB, Yeh KH, Lin JK, Kappeler C, Shapiro J, Kalmus J and Li J: Regorafenib in Chinese patients with metastatic colorectal cancer: Subgroup analysis of the phase 3 CONCUR trial. J Gastroenterol Hepatol 35(8): 1307-1316, 2020. PMID: 31900959. DOI: 10.1111/ jgh. 14974 
24 Riechelmann RP, Leite LS, Bariani GM, Glasberg J, Rivelli TG, da Fonseca LG, Nebuloni DR, Braghiroli MI, Queiroz MA, Isejima AM, Kappeler C, Kikuchi L and Hoff PM: Regorafenib in patients with antiangiogenic-naïve and chemotherapyrefractory advanced colorectal cancer: Results from a phase IIb trial. Oncologist 24(9): 1180-1187, 2019. PMID: 31175167. DOI: 10.1634/theoncologist.2019-0067

25 García-Alfonso P, Benavides M, Falcó E, Muñoz A, Gómez A, Sastre J, Rivera F, Montagut C, Salgado M, López-Ladrón A, López R, Ruiz de Mena I, Durán G and Aranda E; Spanish Cooperative Group for the Treatment of Digestive Tumors (TTD): Single-agent regorafenib in metastatic colorectal cancer patients with any RAS or BRAF mutation previously treated with FOLFOXIRI plus Bevacizumab (PREVIUM Trial). Oncologist 23(11): 1271-e128, 2018. PMID: 30120161. DOI: 10.1634/ theoncologist.2018-0316

26 Shitara K, Yamanaka T, Denda T, Tsuji Y, Shinozaki K, Komatsu Y, Kobayashi Y, Furuse J, Okuda H, Asayama M, Akiyoshi K, Kagawa Y, Kato T, Oki E, Ando T, Hagiwara Y, Ohashi Y and Yoshino T: REVERCE: a randomized phase II study of regorafenib followed by cetuximab versus the reverse sequence for previously treated metastatic colorectal cancer patients. Ann Oncol 30(2): 259-265, 2019. PMID: 30508156. DOI: 10.1093/annonc/mdy526

27 Adenis A, de la Fouchardiere C, Paule B, Burtin P, Tougeron D, Wallet J, Dourthe LM, Etienne PL, Mineur L, Clisant S, Phelip JM, Kramar A and Andre T: Survival, safety, and prognostic factors for outcome with Regorafenib in patients with metastatic colorectal cancer refractory to standard therapies: results from a multicenter study (REBECCA) nested within a compassionate use program. BMC Cancer 16: 412, 2016. PMID: 27389564. DOI: $10.1186 / \mathrm{s} 12885-016-2440-9$

28 Van Cutsem E, Martinelli E, Cascinu S, Sobrero A, Banzi M, Seitz JF, Barone C, Ychou M, Peeters M, Brenner B, Hofheinz RD, Maiello E, André T, Spallanzani A, Garcia-Carbonero R, Arriaga YE, Verma U, Grothey A, Kappeler C, Miriyala A, Kalmus J, Falcone A and Zaniboni A: Regorafenib for patients with metastatic colorectal cancer who progressed after standard therapy: results of the large, single-arm, open-label phase IIIb CONSIGN Study. Oncologist 24(2): 185-192, 2019. PMID: 30190299. DOI: 10.1634/theoncologist.2018-0072

29 Ducreux M, Petersen LN, Öhler L, Bergamo F, Metges JP, de Groot JW, Wang JY, García Paredes B, Dochy E, Fiala-Buskies S, Cervantes A, O'Connor JM and Falcone A; CORRELATE Investigators: Safety and effectiveness of regorafenib in patients with metastatic colorectal cancer in routine clinical practice in the prospective, observational CORRELATE study. Eur J Cancer 123: 146-154, 2019. PMID: 31698328. DOI: 10.1016/j.ejca. 2019.09.015

30 Dane F, Ozgurdal K, Yalçın Ş, Benekli M, Aykan NF, Yücel İ, Özkan M, Evrensel T, Sevinç A, Coskun HŞ, Sanli UA, Kara IO and Yumuk PF: Safety and efficacy of regorafenib in patients with treatment-refractory metastatic colorectal cancer in Turkey: the single-arm, open-label REGARD study. BMJ Open 10(3): e027665, 2020. PMID: 32220908. DOI: 10.1136/bmjopen-2018-027665

31 Sueda T, Sakai D, Kudo T, Sugiura T, Takahashi H, Haraguchi N, Nishimura J, Hata T, Hayashi T, Mizushima T, Doki Y, Mori $\mathrm{M}$ and Satoh T: Efficacy and safety of regorafenib or TAS-102 in patients with metastatic colorectal cancer refractory to standard therapies. Anticancer Res 36(8): 4299-4306, 2016. PMID: 27466548.
32 Temmink OH, Emura T, de Bruin M, Fukushima M and Peters GJ: Therapeutic potential of the dual-targeted TAS-102 formulation in the treatment of gastrointestinal malignancies. Cancer Sci 98(6): 779-789, 2007. PMID: 17441963. DOI: 10.1111/j.1349-7006.2007.00477.x

33 Peters GJ: Therapeutic potential of TAS-102 in the treatment of gastrointestinal malignancies. Ther Adv Med Oncol 7(6): 340356, 2015. PMID: 26557901. DOI: 10.1177/17588340 15603313

34 Yoshino T, Mizunuma N, Yamazaki K, Nishina T, Komatsu Y, Baba H, Tsuji A, Yamaguchi K, Muro K, Sugimoto N, Tsuji Y, Moriwaki T, Esaki T, Hamada C, Tanase T and Ohtsu A: TAS102 monotherapy for pretreated metastatic colorectal cancer: a double-blind, randomised, placebo-controlled phase 2 trial. Lancet Oncol 13(10): 993-1001, 2012. PMID: 22951287. DOI: 10.1016/S1470-2045(12)70345-5

35 Mayer RJ, Van Cutsem E, Falcone A, Yoshino T, GarciaCarbonero R, Mizunuma N, Yamazaki K, Shimada Y, Tabernero J, Komatsu Y, Sobrero A, Boucher E, Peeters M, Tran B, Lenz HJ, Zaniboni A, Hochster H, Cleary JM, Prenen H, Benedetti F, Mizuguchi H, Makris L, Ito M and Ohtsu A; RECOURSE Study Group: Randomized trial of TAS-102 for refractory metastatic colorectal cancer. N Engl J Med 372(20): 1909-1919, 2015. PMID: 25970050. DOI: 10.1056/NEJMoa1414325

36 New Drug Application. Available at: https://www.accessdata. fda.gov/drugsatfda_docs/appletter/2015/207981Orig1 s000ltr.pdf [Last accessed on January 1, 2021]

37 Masuishi T, Taniguchi H, Hamauchi S, Komori A, Kito Y, Narita Y, Tsushima T, Ishihara M, Todaka A, Tanaka T, Yokota T, Kadowaki S, Machida N, Ura T, Fukutomi A, Ando M, Onozawa Y, Tajika M, Yasui H, Muro K, Mori K and Yamazaki K: Regorafenib versus trifluridine/tipiracil for refractory metastatic colorectal cancer: A retrospective comparison. Clin Colorectal Cancer 16(2): e15-e22, 2017. PMID: 27670892. DOI: 10.1016/ j.clcc.2016.07.019

38 Moriwaki T, Fukuoka S, Taniguchi H, Takashima A, Kumekawa Y, Kajiwara T, Yamazaki K, Esaki T, Makiyama C, Denda T, Satake H, Suto T, Sugimoto N, Enomoto M, Ishikawa T, Kashiwada T, Sugiyama M, Komatsu Y, Okuyama H, Baba E, Sakai D, Watanabe T, Tamura T, Yamashita K, Gosho M and Shimada Y: Propensity score analysis of regorafenib versus trifluridine/tipiracil in patients with metastatic colorectal cancer refractory to standard chemotherapy (REGOTAS): A Japanese Society for Cancer of the Colon and Rectum Multicenter Observational Study. Oncologist 23(1): 7-15, 2018. PMID: 28894015. DOI: $10.1634 /$ theoncologist.2017-0275

39 Ogata M, Kotaka M, Ogata T, Hatachi Y, Yasui H, Kato T, Tsuji A and Satake H: Regorafenib $v s$. trifluridine/tipiracil for metastatic colorectal cancer refractory to standard chemotherapies: A multicenter retrospective comparison study in Japan. PLoS One 15(6): e0234314, 2020. PMID: 32530932. DOI: 10.1371/journal. pone. 0234314

40 Ben-Ami E, Barysauskas CM, von Mehren M, Heinrich MC, Corless CL, Butrynski JE, Morgan JA, Wagner AJ, Choy E, Yap JT, Van den Abbeele AD, Solomon SM, Fletcher JA, Demetri GD and George S: Long-term follow-up results of the multicenter phase II trial of regorafenib in patients with metastatic and/or unresectable GI stromal tumor after failure of standard tyrosine kinase inhibitor therapy. Ann Oncol 27(9): 1794-1799, 2016. PMID: 27371698. DOI: 10.1093/annonc/mdw228 
41 Bekaii-Saab TS, Ou FS, Ahn DH, Boland PM, Ciombor KK, Heying EN, Dockter TJ, Jacobs NL, Pasche BC, Cleary JM, Meyers JP, Desnoyers RJ, McCune JS, Pedersen K, Barzi A, Chiorean EG, Sloan J, Lacouture ME, Lenz HJ and Grothey A: Regorafenib dose-optimisation in patients with refractory metastatic colorectal cancer (ReDOS): a randomised, multicentre, open-label, phase 2 study. Lancet Oncol 20(8): 1070-1082, 2019. PMID: 31262657. DOI: 10.1016/S14702045(19)30272-4

42 Suzuki T, Sukawa Y, Imamura CK, Masuishi T, Satake H, Kumekawa Y, Funakoshi S, Kotaka M, Horie Y, Kawai S, Okuda H, Terazawa T, Kondoh C, Kato K, Yoshimura K, Ishikawa H, Hamamoto Y, Boku N, Takaishi H and Kanai T: A phase II study of regorafenib with a lower starting dose in patients with metastatic colorectal cancer: exposure-toxicity analysis of unbound regorafenib and its active metabolites (RESET Trial). Clin Colorectal Cancer 19(1): 13-21.e3, 2020. PMID: 31732439. DOI: $10.1016 /$ j.clcc.2019.10.004

43 Nakashima M, Ide K and Kawakami K: Comparison of standard initial dose and reduced initial dose regorafenib for colorectal cancer patients: a retrospective cohort study. Target Oncol 14(3): 295-306, 2019. PMID: 31093834. DOI: 10.1007/s11523-01900642-8

44 Petrioli R, Chirra M, Messuti L, Fiaschi AI, Savelli V, Martellucci I and Francini E: Efficacy and safety of regorafenib with $2 / 1$ schedule for patients $\geq 75$ years with metastatic colorectal cancer (mCRC) after failure of 2 lines of chemotherapy. Clin Colorectal Cancer 17(4): 307-312, 2018. PMID: 29548772. DOI: 10.1016/j.clcc.2018.02.005

45 Aparicio T, Darut-Jouve A, Khemissa Akouz F, Montérymard C, Artru P, Cany L, Romano O, Valenza B, Le Foll C, Delbaldo C, Falandry C, Norguet Monnereau E, Ben Abdelghani M, Smith D, Rinaldi Y, Père Verge D, Baize N, Maillard E, Dohan A, Des Guetz G, Pamoukdjian F and Lepage C: Single-arm phase II trial to evaluate efficacy and tolerance of regorafenib monotherapy in patients over 70 with previously treated metastatic colorectal adenocarcinoma FFCD 1404 - REGOLD. J Geriatr Oncol 11(8): 1255-1262, 2020. PMID: 32334940. DOI: https://doi.org/ 10.1016/j.jgo.2020.04.001

46 Schultheis B, Folprecht G, Kuhlmann J, Ehrenberg R, Hacker UT, Köhne CH, Kornacker M, Boix O, Lettieri J, Krauss J, Fischer R, Hamann S, Strumberg D and Mross KB: Regorafenib in combination with FOLFOX or FOLFIRI as first- or secondline treatment of colorectal cancer: results of a multicenter, phase Ib study. Ann Oncol 24(6): 1560-1567, 2013. PMID: 23493136. DOI: $10.1093 /$ annonc/mdt056

47 Argilés G, Saunders MP, Rivera F, Sobrero A, Benson A 3rd, Guillén Ponce C, Cascinu S, Van Cutsem E, Macpherson IR, Strumberg D, Köhne CH, Zalcberg J, Wagner A, Luigi Garosi V, Grunert J, Tabernero J and Ciardiello F: Regorafenib plus modified FOLFOX6 as first-line treatment of metastatic colorectal cancer: A phase II trial. Eur J Cancer 51(8): 942-949. PMID: 25818084. DOI: 10.1016/j.ejca.2015.02.013

48 Sanoff HK, Goldberg RM, Ivanova A, O'Reilly S, Kasbari SS, Kim RD, McDermott R, Moore DT, Zamboni W, Grogan W, Cohn AL, Bekaii-Saab TS, Leonard G, Ryan T, Olowokure OO, Fernando NH, McCaffrey J, El-Rayes BF, Horgan AM, Sherrill $\mathrm{GB}$, Yacoub $\mathrm{GH}$ and $\mathrm{O}^{\prime} \mathrm{Neil} \mathrm{BH}$ : Multicenter, randomized, double-blind phase 2 trial of FOLFIRI with regorafenib or placebo as second-line therapy for metastatic colorectal cancer.
Cancer 124(15): 3118-3126, 2018. PMID: 29905927. DOI: $10.1002 /$ cncr.31552

49 Lin CY, Lin TH, Chen CC, Chen MC and Chen CP: Combination chemotherapy with Regorafenib in metastatic colorectal cancer treatment: A single center, retrospective study. PLoS One 13(1): e0190497, 2018. PMID: 29304109. DOI: 10.1371/journal.pone.0190497

50 Ma CJ, Huang CW, Chang TK, Tsai HL, Su WC, Yeh YS, Chen PJ and Wang JY: Oncologic outcomes in metastatic colorectal cancer with regorafenib with FOLFIRI as a third- or fourth-line setting. Transl Oncol 12(3): 502-512. PMID: 30594039. DOI: 10.1016/j.tranon.2018.12.003

51 Ma CJ, Chang TK, Tsai HL, Su WC, Huang CW, Yeh YS, Chang YT and Wang JY: Regorafenib plus FOLFIRI with irinotecan dose escalated according to uridine diphosphate glucuronosyltransferase 1A1genotyping in previous treated metastatic colorectal cancer patients: study protocol for a randomized controlled trial. Trials 20(1): 751, 2019. PMID: 31856912. DOI: 10.1186/s13063-019-3917-z

52 Moehler MH, Stein A, Trojan J, Marquardt JU, Quidde J, Waidmann O, Weinmann A, Woerns M, Schroeder H, Maenz M, Karatas A and Foerster F: Regorafenib with TAS-102 (REGOTAS) in metastatic colorectal cancer patients who progressed after at least two standard therapies: Efficacy and safety results of a multicenter phase I study (REMETY). J Clin Oncol 38(4_suppl): 158-158, 2020. DOI: 10.1200/JCO.2020.38.4_suppl.158

53 Fukuoka S, Hara H, Takahashi N, Kojima T, Kawazoe A, Asayama M, Yoshii T, Kotani D, Tamura H, Mikamoto Y, Hirano N, Wakabayashi M, Nomura S, Sato A, Kuwata T, Togashi Y, Nishikawa $\mathrm{H}$ and Shitara K: Regorafenib plus nivolumab in patients with advanced gastric or colorectal cancer: an openlabel, dose-escalation, and dose-expansion phase Ib Trial (REGONIVO, EPOC1603). J Clin Oncol 38(18): 2053-2061, 2020. PMID: 32343640. DOI: 10.1200/JCO.19.03296

54 Hoff S, Grünewald S, Röse L and Zopf D: Immunomodulation by regorafenib alone and in combination with anti PD1 antibody on murine models of colorectal cancer. Ann Oncol 28(suppl_5): v403-v427, 2017. DOI: 10.1093/annonc/mdx376

55 Mantovani A, Marchesi F, Malesci A, Laghi L and Allavena P: Tumour-associated macrophages as treatment targets in oncology. Nat Rev Clin Oncol 14(7): 399-416, 2017. PMID: 28117416. DOI: $10.1038 /$ nrclinonc. 2016.217

56 Tada Y, Togashi Y, Kotani D, Kuwata T, Sato E, Kawazoe A, Doi T, Wada H, Nishikawa H and Shitara K: Targeting VEGFR2 with Ramucirumab strongly impacts effector/ activated regulatory $\mathrm{T}$ cells and CD8+ $\mathrm{T}$ cells in the tumor microenvironment. $\mathrm{J}$ Immunother Cancer 6(1): 106, 2018. PMID: 30314524. DOI: 10.1186/s40425-018-0403-1

57 Røed Skårderud M, Polk A, Kjeldgaard Vistisen K, Larsen FO and Nielsen DL: Efficacy and safety of regorafenib in the treatment of metastatic colorectal cancer: A systematic review. Cancer Treat Rev 62: 61-73, 2018. PMID: 29175677. DOI: 10.1016/j.ctrv.2017.10.011

58 Xue WS, Men SY, Liu W and Liu RH: A meta-analysis of safety and efficacy of regorafenib for refractory metastatic colorectal cancer. Medicine (Baltimore) 97(40): e12635, 2018. PMID: 30290640. DOI: 10.1097/MD.0000000000012635

59 Abrahao ABK, Ko YJ, Berry S and Chan KKW: A comparison of regorafenib and TAS-102 for metastatic colorectal cancer: A systematic review and network meta-analysis. Clin Colorectal 
Cancer 17(2): 113-120, 2018. PMID: 29174481. DOI: 10.1016/j.clcc.2017.10.016

60 Mayer RJ, Van Cutsem E, Falcone A, Yoshino T, GarciaCarbonero R, Mizunuma N, Yamazaki K, Shimada Y, Tabernero J, Komatsu Y, Sobrero A, Boucher E, Peeters M, Tran B, Lenz HJ, Zaniboni A, Hochster H, Cleary JM, Prenen H, Benedetti F, Mizuguchi H, Makris L, Ito M and Ohtsu A; RECOURSE Study Group: Randomized trial of TAS-102 for refractory metastatic colorectal cancer. N Engl J Med 372(20): 1909-1919, 2015. PMID: 25970050. DOI: 10.1056/NEJMoa1414325

61 Sonbol MB, Benkhadra R, Wang Z, Firwana B, Walden DJ, Mody K, Hubbard JM, Murad MH, Ahn DH and Bekaii-Saab T: A systematic review and network meta-analysis of regorafenib and TAS-102 in refractory metastatic colorectal cancer. Oncologist 24(9): 1174-1179, 2019. PMID: 31164455, DOI: 10.1634/theoncologist.2019-0189

62 Xu J, Kim TW, Shen L, Sriuranpong V, Pan H, Xu R, Guo W, Han SW, Liu T, Park YS, Shi C, Bai Y, Bi F, Ahn JB, Qin S, Li Q, Wu C, Ma D, Lin D and Li J: Results of a randomized, double-blind, placebo-controlled, phase III trial of trifluridine/tipiracil (TAS-102) monotherapy in asian patients with previously treated metastatic colorectal cancer: The TERRA Study. J Clin Oncol 36(4): 350-358, 2018. PMID: 29215955. DOI: $10.1200 / J C O .2017 .74 .3245$

63 Yoshino T, Mizunuma N, Yamazaki K, Nishina T, Komatsu Y, Baba H, Tsuji A, Yamaguchi K, Muro K, Sugimoto N, Tsuji Y, Moriwaki T, Esaki T, Hamada C, Tanase T and Ohtsu A: TAS102 monotherapy for pretreated metastatic colorectal cancer: a double-blind, randomised, placebo-controlled phase 2 trial. Lancet Oncol 13(10): 993-1001, 2012. PMID: 22951287. DOI: 10.1016/S1470-2045(12)70345-5

64 Chen J, Wang J, Lin H and Peng Y: Comparison of regorafenib, fruquintinib and TAS-102 in previously treated patients with metastatic colorectal cancer: a systematic review and network meta-analysis of five clinical trials. Med Sci Monit 25: 91799191, 2019. PMID: 31790382. DOI: 10.12659/MSM.918411

65 Zhang Q, Wang Q, Wang X, Li J, Shen L and Peng Z: Regorafenib, TAS-102, or fruquintinib for metastatic colorectal cancer: any difference in randomized trials? Int J Colorectal Dis 35(2): 295-306, 2020. PMID: 31848739. DOI: 10.1007/s00384019-03477-x

66 Wu Y, Fan Y, Dong D, Dong X, Hu Y, Shi Y, Jing J and Li E: Efficacy and safety of regorafenib as beyond second-line therapy in patients with metastatic colorectal cancer: an adjusted indirect meta-analysis and systematic review. Ther Adv Med Oncol 12: 1758835920940932, 2020. PMID: 32728393. DOI: 10.1177/ 1758835920940932

67 Wilhelm SM, Carter C, Tang L, Wilkie D, McNabola A, Rong H, Chen C, Zhang X, Vincent P, McHugh M, Cao Y, Shujath J, Gawlak S, Eveleigh D, Rowley B, Liu L, Adnane L, Lynch M, Auclair D, Taylor I, Gedrich R, Voznesensky A, Riedl B, Post LE, Bollag G and Trail PA: BAY 43-9006 exhibits broad spectrum oral antitumor activity and targets the RAF/MEK/ERK pathway and receptor tyrosine kinases involved in tumor progression and angiogenesis. Cancer Res 64(19): 7099-109, 2004. PMID: 15466206. DOI: 10.1158/0008-5472.CAN-04-1443

68 Carlomagno F, Anaganti S, Guida T, Salvatore G, Troncone G, Wilhelm SM and Santoro M: BAY 43-9006 inhibition of oncogenic RET mutants. J Natl Cancer Inst 98(5): 326-334, 2006. PMID: 16507829 . DOI: $10.1093 /$ jnci/djj069
69 Kircher SM, Nimeiri HS and Benson AB 3rd: Targeting Angiogenesis in Colorectal Cancer: Tyrosine Kinase Inhibitors. Cancer J 22(3): 182-189, 2016. PMID: 27341596. DOI: 10.1097/PPO.0000000000000192

70 Tabernero J, Garcia-Carbonero R, Cassidy J, Sobrero A, Van Cutsem E, Köhne CH, Tejpar S, Gladkov O, Davidenko I, Salazar R, Vladimirova L, Cheporov S, Burdaeva O, Rivera F, Samuel L, Bulavina I, Potter V, Chang YL, Lokker NA and O'Dwyer PJ: Sorafenib in combination with oxaliplatin, leucovorin, and fluorouracil (modified FOLFOX6) as first-line treatment of metastatic colorectal cancer: the RESPECT trial. Clin Cancer Res 19(9): 2541-2550, 2013. PMID: 23532888. DOI: 10.1158/1078-0432.CCR-13-0107

71 Samalin E, Fouchardière C, Thézenas S, Boige V, Senellart H, Guimbaud R, Taïeb J, François E, Galais MP, Lièvre A, Seitz JF, Metges JP, Bouché O, Boissière-Michot F, Lopez-Crapez E, Bibeau F, Ho-Pun-Cheung A, Ychou M, Adenis A, Di Fiore F and Mazard T: Sorafenib plus irinotecan combination in patients with RAS-mutated metastatic colorectal cancer refractory to standard combined chemotherapies: A multicenter, randomized phase 2 trial (NEXIRI-2/PRODIGE 27). Clin Colorectal Cancer 19(4): 301-310.e1, 2020. PMID: 32737004. DOI: 10.1016/j.clcc. 2020.04 .008

72 Potapova O, Laird AD, Nannini MA, Barone A, Li G, Moss KG, Cherrington JM and Mendel DB: Contribution of individual targets to the antitumor efficacy of the multitargeted receptor tyrosine kinase inhibitor SU11248. Mol Cancer Ther 5(5): 12801289, 2006. PMID: 16731761. DOI: 10.1158/1535-7163.MCT03-0156

73 Mena AC, Pulido EG and Guillén-Ponce C: Understanding the molecular-based mechanism of action of the tyrosine kinase inhibitor: sunitinib. Anticancer Drugs 21(Suppl 1): S3-11, 2010. PMID: 20110785. DOI: 10.1097/01.cad.0000361534.44052.c5

74 Saltz LB, Rosen LS, Marshall JL, Belt RJ, Hurwitz HI, Eckhardt SG, Bergsland EK, Haller DG, Lockhart AC, Rocha Lima CM, Huang X, DePrimo SE, Chow-Maneval E, Chao RC and Lenz HJ: Phase II trial of sunitinib in patients with metastatic colorectal cancer after failure of standard therapy. J Clin Oncol 25(30): 4793-4799, 2007. PMID: 17947727. DOI: 10.1200/ JCO.2007.12.8637

75 Starling N, Vázquez-Mazón F, Cunningham D, Chau I, Tabernero J, Ramos FJ, Iveson TJ, Saunders MP, Aranda E, Countouriotis AM, Ruiz-Garcia A, Wei G, Tursi JM, Guillen-Ponce C and Carrato A: A phase I study of sunitinib in combination with FOLFIRI in patients with untreated metastatic colorectal cancer. Ann Oncol 23(1): 119-127, 2012. PMID: 21447616. DOI: 10.1093/annonc/mdr046

76 Carrato A, Swieboda-Sadlej A, Staszewska-Skurczynska M, Lim R, Roman L, Shparyk Y, Bondarenko I, Jonker DJ, Sun Y, De la Cruz JA, Williams JA, Korytowsky B, Christensen JG, Lin X, Tursi JM, Lechuga MJ and Van Cutsem E: Fluorouracil, leucovorin, and irinotecan plus either sunitinib or placebo in metastatic colorectal cancer: a randomized, phase III trial. J Clin Oncol 31(10): 1341-1347, 2913. PMID: 23358972. DOI: 10.1200/JCO.2012.45.1930

77 Mross K, Scheulen M, Strumberg D, Kuhlmann J, Kanefendt F, Sörgel F, Jaehde U, Burkholder I, Moritz B and Büchert M: FOLFIRI and sunitinib as first-line treatment in metastatic colorectal cancer patients with liver metastases--a CESAR phase II study including pharmacokinetic, biomarker, and imaging data. 
Int J Clin Pharmacol Ther 52(8): 642-652, 2014. PMID: 24800922. DOI: $10.5414 / \mathrm{CP} 202109$

78 Wood JM, Bold G, Buchdunger E, Cozens R, Ferrari S, Frei J, Hofmann F, Mestan J, Mett H, O'Reilly T, Persohn E, Rösel J, Schnell C, Stover D, Theuer A, Towbin H, Wenger F, WoodsCook K, Menrad A, Siemeister G, Schirner M, Thierauch KH, Schneider MR, Drevs J, Martiny-Baron G and Totzke F: PTK787/ZK 222584, a novel and potent inhibitor of vascular endothelial growth factor receptor tyrosine kinases, impairs vascular endothelial growth factor-induced responses and tumor growth after oral administration. Cancer Res 60(8): 2178-2189, 2000. PMID: 10786682.

79 Thomas AL, Trarbach T, Bartel C, Laurent D, Henry A, Poethig M, Wang J, Masson E, Steward W, Vanhoefer $U$ and Wiedenmann B: A phase IB, open-label dose-escalating study of the oral angiogenesis inhibitor PTK787/ZK 222584 (PTK/ZK), in combination with FOLFOX4 chemotherapy in patients with advanced colorectal cancer. Ann Oncol 18(4): 782-788, 2007. PMID: 17218488. DOI: 10.1093/annonc/mdl469

80 Trarbach T, Schleucher N, Tewes M, Seeber S, Junker U, Laurent D, Vanhoefer U, Masson E and Lebwohl D: Phase I/II study of PTK787/ZK 222584 (PTK/ZK), a novel, oral angiogenesis inhibitor in combination with FOLFIRI as first-line treatment for patients with metastatic colorectal cancer (CRC). J Clin Oncol 23(16_suppl): 3605-3605, 2005. DOI: 10.1200/jco.2004. 22.90140 .3558

81 Hecht JR, Trarbach T, Hainsworth JD, Major P, Jäger E, Wolff RA, Lloyd-Salvant K, Bodoky G, Pendergrass K, Berg W, Chen BL, Jalava T, Meinhardt G, Laurent D, Lebwohl D and Kerr D: Randomized, placebo-controlled, phase III study of first-line oxaliplatin-based chemotherapy plus PTK787/ZK 222584, an oral vascular endothelial growth factor receptor inhibitor, in patients with metastatic colorectal adenocarcinoma. J Clin Oncol 29(15): 1997-2003, 2011. PMID: 21464406. DOI: 10.1200/ JCO.2010.29.4496

82 Van Cutsem E, Bajetta E, Valle J, Köhne CH, Hecht JR, Moore M, Germond C, Berg W, Chen BL, Jalava T, Lebwohl D, Meinhardt G, Laurent D and Lin E: Randomized, placebocontrolled, phase III study of oxaliplatin, fluorouracil, and leucovorin with or without PTK787/ZK 222584 in patients with previously treated metastatic colorectal adenocarcinoma. J Clin Oncol 29(15): 2004-2010, 2011. PMID: 21464401. DOI: 10.1200/JCO.2010.29.5436

83 Nakamura K, Taguchi E, Miura T, Yamamoto A, Takahashi K, Bichat F, Guilbaud N, Hasegawa K, Kubo K, Fujiwara Y, Suzuki R, Kubo K, Shibuya M and Isae T: KRN951, a highly potent inhibitor of vascular endothelial growth factor receptor tyrosine kinases, has antitumor activities and affects functional vascular properties. Cancer Res 66(18): 9134-9142, 2006. PMID: 16982756. DOI: $10.1158 / 0008-5472 . C A N-05-4290$

84 Oldenhuis CN, Loos WJ, Esteves B, van Doorn L, Cotreau MM, Strahs AL, den Hollander MW, Gietema JA, de Vries EG and Eskens FA: A phase Ib study of the VEGF receptor tyrosine kinase inhibitor tivozanib and modified FOLFOX-6 in patients with advanced gastrointestinal malignancies. Clin Colorectal Cancer 14(1): 18-24.e1, 2015. PMID: 25591799. DOI: 10.1016/j.clcc.2014.12.001

85 Benson AB 3rd, Kiss I, Bridgewater J, Eskens FA, Sasse C, Vossen S, Chen J, Van Sant C, Ball HA, Keating A and Krivoshik A: BATON-CRC: A phase II randomized trial comparing tivozanib plus mFOLFOX6 with bevacizumab plus mFOLFOX6 in stage IV metastatic colorectal cancer. Clin Cancer Res 22(20): 5058-5067, 2016. PMID: 27401244. DOI: 10.1158/10780432.CCR-15-3117

86 Herbst RS, Heymach JV, O'Reilly MS, Onn A and Ryan AJ: Vandetanib (ZD6474): an orally available receptor tyrosine kinase inhibitor that selectively targets pathways critical for tumor growth and angiogenesis. Expert Opin Investig Drugs 16(2): 239-249, 2007. PMID: 17243944. DOI: 10.1517/ 13543784.16.2.239

87 Meyerhardt JA, Ancukiewicz M, Abrams TA, Schrag D, Enzinger PC, Chan JA, Kulke MH, Wolpin BM, Goldstein M, Blaszkowsky L, Zhu AX, Elliott M, Regan E, Jain RK and Duda DG: Phase I study of cetuximab, irinotecan, and vandetanib (ZD6474) as therapy for patients with previously treated metastastic colorectal cancer. PLoS One 7(6): e38231, 2012. PMID: 22701615. DOI: 10.1371/journal.pone.0038231

88 Cabebe EC, Fisher GA and Sikic BI: A phase I trial of vandetanib combined with capecitabine, oxaliplatin and bevacizumab for the first-line treatment of metastatic colorectal cancer. Invest New Drugs 30(3): 1082-1087, 2012. PMID: 21404105. DOI: 10.1007/s10637-011-9656-y

89 Hilberg F, Roth GJ, Krssak M, Kautschitsch S, Sommergruber W, Tontsch-Grunt U, Garin-Chesa P, Bader G, Zoephel A, Quant J, Heckel A and Rettig WJ: BIBF 1120: triple angiokinase inhibitor with sustained receptor blockade and good antitumor efficacy. Cancer Res 68(12): 4774-4782, 2008. PMID: 18559524. DOI: 10.1158/0008-5472.CAN-07-6307

90 Van Cutsem E, Prenen H, D'Haens G, Bennouna J, Carrato A, Ducreux M, Bouché O, Sobrero A, Latini L, Staines H, Oum'Hamed Z, Dressler H, Studeny M and Capdevila J: A phase I/II, open-label, randomised study of nintedanib plus mFOLFOX6 versus bevacizumab plus mFOLFOX6 in first-line metastatic colorectal cancer patients. Ann Oncol 26(10): 20852091, 2015. PMID: 26272806. DOI: 10.1093/annonc/mdv286

91 Van Cutsem E, Yoshino T, Lenz HJ, Lonardi S, Falcone A, Limón ML, Saunders M, Sobrero A, Park YS, Ferreiro R, Hong YS, Tomasek J, Taniguchi H, Ciardiello F, Stoehr J, Oum'Hamed Z, Vlassak S, Studeny M and Argiles G: Nintedanib for the treatment of patients with refractory metastatic colorectal cancer (LUME-Colon 1): a phase III, international, randomized, placebo-controlled study. Ann Oncol 29(9): 1955-1963, 2018. PMID: 30010751. DOI: 10.1093/annonc/mdy241

92 Sun Q, Zhou J, Zhang Z, Guo M, Liang J, Zhou F, Long J, Zhang W, Yin F, Cai H, Yang H, Zhang W, Gu Y, Ni L, Sai Y, Cui Y, Zhang M, Hong M, Sun J, Yang Z, Qing W, Su W and Ren Y: Discovery of fruquintinib, a potent and highly selective small molecule inhibitor of VEGFR 1, 2, 3 tyrosine kinases for cancer therapy. Cancer Biol Ther 15(12): 1635-1645, 2014. PMID: 25482937. DOI: 10.4161/15384047.2014.964087

93 Xu RH, Li J, Bai Y, Xu J, Liu T, Shen L, Wang L, Pan H, Cao J, Zhang D, Fan S, Hua Y and Su W: Safety and efficacy of fruquintinib in patients with previously treated metastatic colorectal cancer: a phase Ib study and a randomized doubleblind phase II study. J Hematol Oncol 10(1): 22, 2017. PMID: 28103904. DOI: 10.1186/s13045-016-0384-9

94 Li J, Qin S, Xu RH, Shen L, Xu J, Bai Y, Yang L, Deng Y, Chen ZD, Zhong H, Pan H, Guo W, Shu Y, Yuan Y, Zhou J, Xu N, Liu T, Ma D, Wu C, Cheng Y, Chen D, Li W, Sun S, Yu Z, Cao P, Chen H, Wang J, Wang S, Wang H, Fan S, Hua Y and Su W: 
Effect of fruquintinib vs placebo on overall survival in patients with previously treated metastatic colorectal cancer: The FRESCO randomized clinical trial. JAMA 319(24): 2486-2496, 2018. PMID: 29946728. DOI: 10.1001/jama.2018.7855

95 CHI-MED News and Presentations: Available at: https://www.chi-med.com/fruquintinib-granted-us-fda-fast-trackdesignation-for-mcrc/ [Last accessed on January 1, 2021]

96 ChemIDplus. Available at: https://chem.nlm.nih.gov/ chemidplus/sid/0945380278 [Last accessed on January 1, 2021]

97 Xu RH, Shen L, Wang KM, Wu G, Shi CM, Ding KF, Lin LZ, Wang JW, Xiong JP, Wu CP, Li J, Liu YP, Wang D, Ba Y, Feng JP, Bai YX, Bi JW, Ma LW, Lei J, Yang Q and Yu H: Famitinib versus placebo in the treatment of refractory metastatic colorectal cancer: a multicenter, randomized, double-blinded, placebocontrolled, phase II clinical trial. Chin J Cancer 36(1): 97, 2017. PMID: 29273089. DOI: 10.1186/s40880-017-0263-y

98 Hu-Lowe DD, Zou HY, Grazzini ML, Hallin ME, Wickman GR, Amundson K, Chen JH, Rewolinski DA, Yamazaki S, Wu EY, McTigue MA, Murray BW, Kania RS, O'Connor P, Shalinsky DR and Bender SL: Nonclinical antiangiogenesis and antitumor activities of axitinib (AG-013736), an oral, potent, and selective inhibitor of vascular endothelial growth factor receptor tyrosine kinases 1, 2, 3. Clin Cancer Res 14(22): 7272-7283, 2008. PMID: 19010843. DOI: 10.1158/1078-0432.CCR-08-0652

99 Infante JR, Reid TR, Cohn AL, Edenfield WJ, Cescon TP, Hamm JT, Malik IA, Rado TA, McGee PJ, Richards DA, Tarazi J, Rosbrook B, Kim S and Cartwright TH: Axitinib and/or bevacizumab with modified FOLFOX-6 as first-line therapy for metastatic colorectal cancer: a randomized phase 2 study. Cancer 119(14): 2555-2563, 2013. PMID: 23605883. DOI: 10.1002/ cncr.28112
100 Bendell JC, Tournigand C, Swieboda-Sadlej A, Barone C, Wainberg ZA, Kim JG, Pericay C, Pastorelli D, Tarazi J, Rosbrook B, Bloom J, Ricart AD, Kim S and Sobrero AF: Axitinib or bevacizumab plus FOLFIRI or modified FOLFOX-6 after failure of first-line therapy for metastatic colorectal cancer: a randomized phase II study. Clin Colorectal Cancer 12(4): 239247, 2013. PMID: 24188685. DOI: 10.1016/j.clcc.2013.09.001

101 Grávalos C, Carrato A, Tobeña M, Rodriguez-Garrote M, Soler G, Vieitez JM, Robles L, Valladares-Ayerbes M, Polo E, Limón ML, Safont MJ, Martínez de Castro E, García-Alfonso P and Aranda E; Spanish Cooperative Group for the Treatment of Digestive Tumors (TTD): A randomized phase II study of axitinib as maintenance therapy after first-line treatment for metastatic colorectal cancer. Clin Colorectal Cancer 17(2): e323e329, 2018. PMID: 29551560. DOI: 10.1016/j.clcc.2018.02.004

102 Tian S, Quan H, Xie C, Guo H, Lü F, Xu Y, Li J and Lou L: YN968D1 is a novel and selective inhibitor of vascular endothelial growth factor receptor-2 tyrosine kinase with potent activity in vitro and in vivo. Cancer Sci 102(7): 1374-1380, 2011. PMID: 21443688. DOI: 10.1111/j.1349-7006.2011.01939.x

103 Liang L, Wang L, Zhu P, Xia Y, Qiao Y, Wu J, Zhuang W, Fei J, Wen $\mathrm{Y}$ and Jiang $\mathrm{X}$ : A pilot study of apatinib as third-line treatment in patients with heavily treated metastatic colorectal cancer. Clin Colorectal Cancer 17(3): e443-e449, 2018. PMID: 29576426. DOI: 10.1016/j.clcc.2018.02.01

Received December 1, 2020 Revised December 31, 2020 Accepted January 4, 2021 